September[2010]

\title{
Field Demonstration of Ground-Source Integrated Heat Pump - Final Report
}

\section{Principal Investigator: Van Baxter}

Prepared for the U.S. Department of Energy By:

\section{Van Baxter} Jeffrey Munk Anthony Gehl

Oak Ridge National Labortaory 


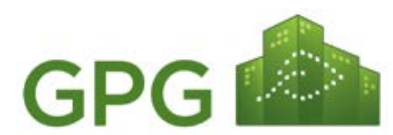

Green Proving Ground Program
The Department of Energy's technology demonstrations are conducted in cooperation with the General Service Administration's Green Proving Ground program. The Green Proving Ground leverages GSA's real estate portfolio to evaluate innovative sustainable building technologies and practices, while the Department of Energy-funded technology demonstrations are conducted in both federal and non-federal buildings. Findings are used to support the development of GSA and DOE performance specifications and inform decision-making within federal agencies and the real estate industry. The programs aim to drive innovation in energy and environmental performance in buildings and help lead market transformation through deployment of new technologies. Learn more at GSA.gov/GreenProvingGround and CommercialBuildings.energy.gov/TechDemo 


\section{Disclaimer}

This document was prepared as an account of work sponsored by the United States Government. While this document is believed to contain correct information, neither the United States Government nor any agency thereof, nor Oak Ridge National Laboratory, nor any of their employees, makes any warranty, express or implied, or assumes any legal responsibility for the accuracy, completeness, or usefulness of any information, apparatus, product, or process disclosed, or represents that its use would not infringe privately owned rights. Reference herein to any specific commercial product, process, or service by its trade name, trademark, manufacturer, or otherwise, does not constitute or imply its endorsement, recommendation, or favoring by the United States Government or any agency thereof, or Oak Ridge National Laboratory. The views and opinions of authors expressed herein do not necessarily state or reflect those of the United States Government or any agency thereof or Oak Ridge National Laboratory.

The work described in this report was funded by the, U.S. Department of Energy under Contract No. DE-AC0500OR22725 with UT-Battelle, LLC.

\section{Acknowledgements}

ClimateMaster, Inc.: Shawn Hern and Jeremy Smith

City Heat \& Air Conditioning, Knoxville, TN: Mike Davis

Comfortworks, Inc., Goldsby, OK: Dan Ellis

ORNL: Geoff Ormston, Randy Linkous, and Melissa Lapsa

United States Department of Energy (DOE): Charles Llenza

For more information contact:

Charles Llenza

Project Manager/Engineer

US Department of Energy

1000 Independence Ave, SW

Mail Stop EE-5B

Washington, DC 20585-0121

techdemo@ee.doe.gov

Van Baxter

Building Equipment Research Group

Energy and Transportation Science Division

Oak Ridge National Laboratory

Post Office Box 2008

Mail Stop 6070

Oak Ridge, TN 37831-6070

baxtervd@ornl.gov 


\title{
DOCUMENT AVAILABILITY
}

Reports produced after January 1, 1996, are generally available free via US Department of Energy (DOE) SciTech Connect.

Website http://www.osti.gov/scitech/

Reports produced before January 1, 1996, may be purchased by members of the public from the following source:

\author{
National Technical Information Service \\ 5285 Port Royal Road \\ Springfield, VA 22161 \\ Telephone 703-605-6000 (1-800-553-6847) \\ TDD 703-487-4639 \\ Fax 703-605-6900 \\ E-mail info@ntis.gov \\ Website http://www.ntis.gov/help/ordermethods.aspx
}

Reports are available to DOE employees, DOE contractors, Energy Technology Data Exchange representatives, and International Nuclear Information System representatives from the following source:

Office of Scientific and Technical Information

PO Box 62

Oak Ridge, TN 37831

Telephone 865-576-8401

Fax 865-576-5728

E-mail reports@osti.gov

Website http://www.osti.gov/contact.html

This report was prepared as an account of work sponsored by an agency of the United States Government. Neither the United States Government nor any agency thereof, nor any of their employees, makes any warranty, express or implied, or assumes any legal liability or responsibility for the accuracy, completeness, or usefulness of any information, apparatus, product, or process disclosed, or represents that its use would not infringe privately owned rights. Reference herein to any specific commercial product, process, or service by trade name, trademark, manufacturer, or otherwise, does not necessarily constitute or imply its endorsement, recommendation, or favoring by the United States Government or any agency thereof. The views and opinions of authors expressed herein do not necessarily state or reflect those of the United States Government or any agency thereof. 


\title{
DOCUMENT AVAILABILITY
}

Reports produced after January 1, 1996, are generally available free via US Department of Energy (DOE) SciTech Connect.

Website http://www.osti.gov/scitech/

Reports produced before January 1, 1996, may be purchased by members of the public from the following source:

\author{
National Technical Information Service \\ 5285 Port Royal Road \\ Springfield, VA 22161 \\ Telephone 703-605-6000 (1-800-553-6847) \\ TDD 703-487-4639 \\ Fax 703-605-6900 \\ E-mail info@ntis.gov \\ Website http://www.ntis.gov/help/ordermethods.aspx
}

Reports are available to DOE employees, DOE contractors, Energy Technology Data Exchange representatives, and International Nuclear Information System representatives from the following source:

Office of Scientific and Technical Information

PO Box 62

Oak Ridge, TN 37831

Telephone 865-576-8401

Fax 865-576-5728

E-mail reports@osti.gov

Website http://www.osti.gov/contact.html

This report was prepared as an account of work sponsored by an agency of the United States Government. Neither the United States Government nor any agency thereof, nor any of their employees, makes any warranty, express or implied, or assumes any legal liability or responsibility for the accuracy, completeness, or usefulness of any information, apparatus, product, or process disclosed, or represents that its use would not infringe privately owned rights. Reference herein to any specific commercial product, process, or service by trade name, trademark, manufacturer, or otherwise, does not necessarily constitute or imply its endorsement, recommendation, or favoring by the United States Government or any agency thereof. The views and opinions of authors expressed herein do not necessarily state or reflect those of the United States Government or any agency thereof. 
ORNL/TM-2016/474

Energy and Transportation Science Division

\title{
Field Demonstration of Ground-Source Integrated Heat Pump -
} Final Report

\author{
Van Baxter \\ Jeff Munk \\ Anthony Gehl
}

September 2016

\author{
Prepared by \\ OAK RIDGE NATIONAL LABORATORY \\ Oak Ridge, Tennessee 37831-6283 \\ managed by \\ UT-BATTELLE, LLC \\ for the \\ US DEPARTMENT OF ENERGY \\ under contract DE-AC05-00OR22725
}




\section{Preface}

This is the last of two reports for the Ground-Source Integrated Heat Pump (GS-IHP) demonstration project.

Report 1: Field Demonstration of Ground-Source Integrated Heat Pump - Part I. Technology and Field Demo System/Site Descriptions, and Preliminary Summer/Fall Performance Analysis for One Site.

This volume provides detailed descriptions of the two test sites and the GS-IHP demonstration system. One was located in Knoxville, TN and the second in Oklahoma City, OK. Both are in the small commercial category (under $10,000 \mathrm{ft}^{2}$ floor space). A description of the GS-IHP technology is also provided along with details of the measurement and performance analysis plans. Due to a protracted construction schedule for the Oklahoma City site, this report only includes preliminary summer/fall performance data and analysis for the Knoxville site.

\section{Report 2: Field Demonstration of Ground-Source Integrated Heat Pump - Final Report}

This second volume provides cooling, heating, and spring season performance comparisons for the GSIHP vs. the baseline in the Oklahoma City location. It also summarizes annual performance of the test system in Knoxville with comparisons vs. the baseline. A cost-effectiveness analysis of the GS-IHP vs. the baseline is included. 


\section{Contents}



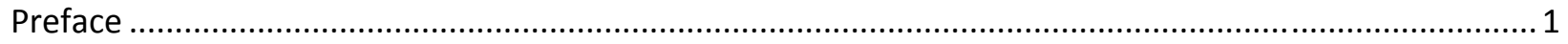

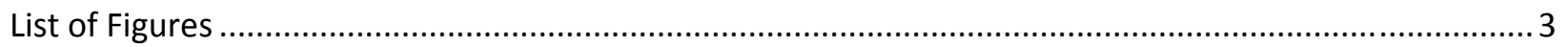



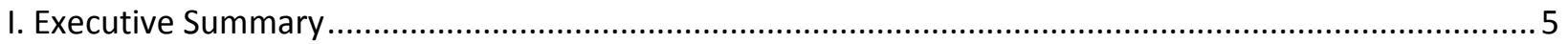

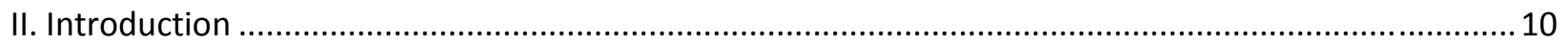

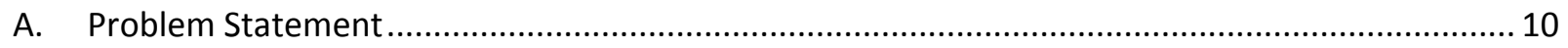

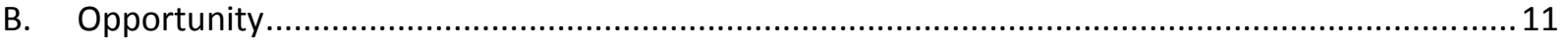

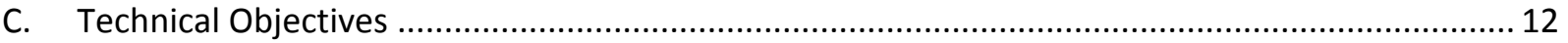

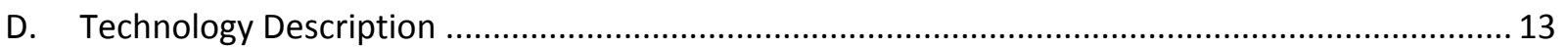

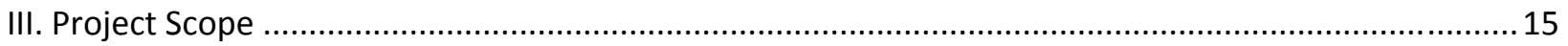

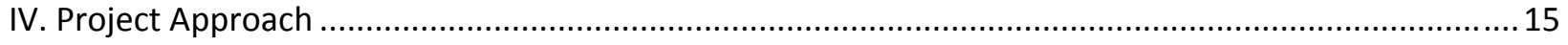

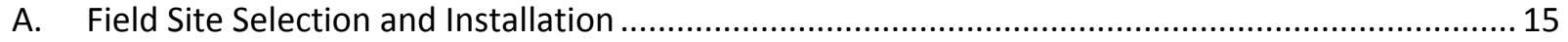

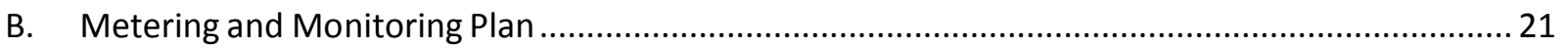

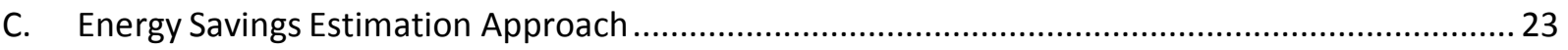

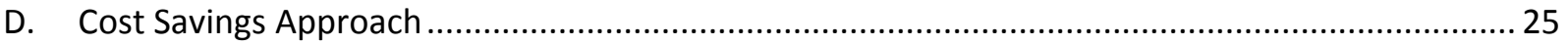

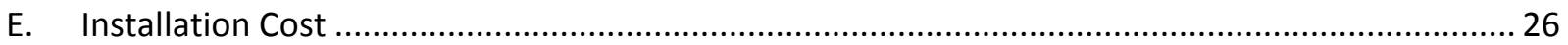

F. GS-IHP Control Verification, Performance-Related Issues, and Installation and Maintenance ..... 29

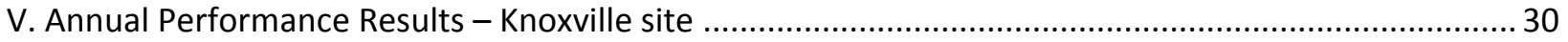

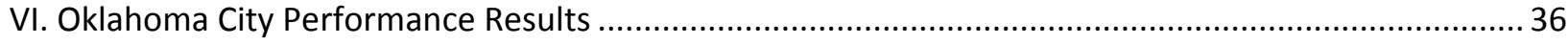

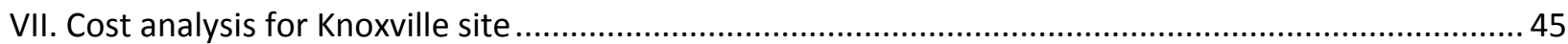

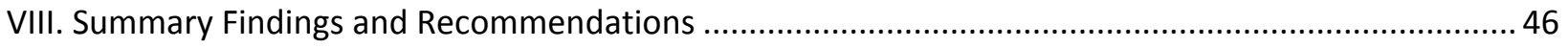

A. Overall Technology Assessment at Demonstration Facility ........................................................ 46

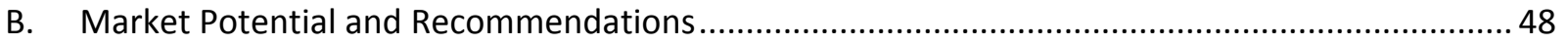

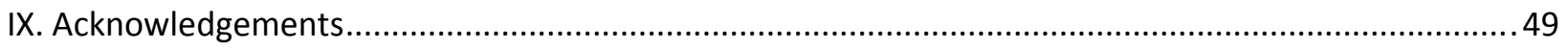




\section{List of Figures}

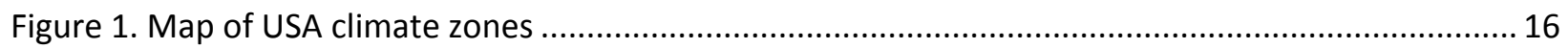

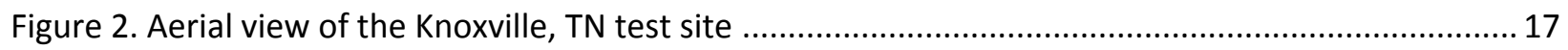

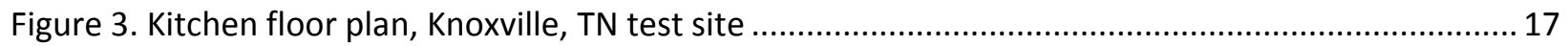

Figure 4. Trilogy WSHP system as installed at the Knoxville, TN test site ............................................. 18

Figure 5. WH piping connections and flowmeters at Knoxville site. ..................................................... 18

Figure 6. GHX loop location and schematic for Knoxville, TN test site .................................................. 19

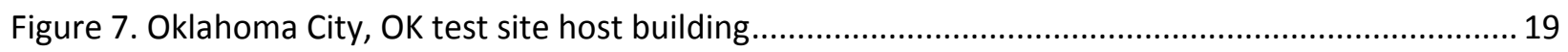

Figure 8. Oklahoma City, OK building mechanical room floor plan; Trilogy units are HP-1 and HP-2....... 20

Figure 9. Oklahoma City host building mechanical room; instrumented Trilogy is on lh side against back

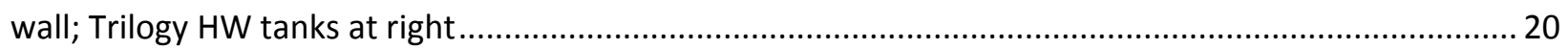

Figure 10. GHX loop location and details for Oklahoma City, OK test site ........................................... 21

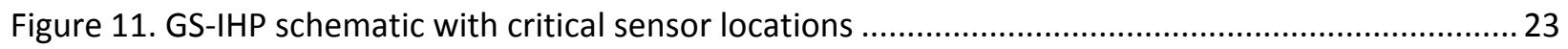

Figure 12. GHX loop headers attached to wall outside kitchen facility, Knoxville site .............................27

Figure 13. Knoxville: Trilogy WSHP vs. Baseline RTU/heat pump SC-only monthly average COPs ............ 32

Figure 14. Knoxville: Trilogy WSHP EWT vs. OAT during Aug-Dec test period ......................................... 33

Figure 15. Knoxville: Kitchen space temperature measured at thermostat during test year .................... 34

Figure 16. Knoxville: Maximum IHP hourly peak demand week .......................................................... 35

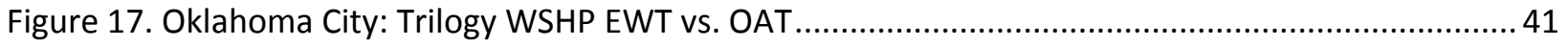

Figure 18. Oklahoma City: Maximum SH season IHP hourly peak demand week ...................................... 43

Figure 19. Oklahoma City: June IHP hourly peak demand week ........................................................... 44



Figure 21. Oklahoma City: August IHP hourly peak demand week ...................................................... 45 


\section{List of Tables}

Table 1. Summary of GS-IHP versus conventional RTU + Electric Storage WH ....................................... 14

Table 2. Description of USA climate zones (Source: ANSI/ASHRAE/IESNA Standard 90.1-2007).............. 16

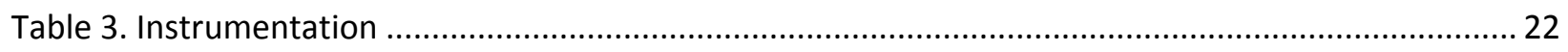

Table 4. Knoxville: GS-IHP summary performance comparison vs. baseline system ................................ 30

Table 5. Knoxville: Approximate overall average GS-IHP COPs by operation mode ................................. 32

Table 6. Knoxville: Peak hourly kW demand by month, GS-IHP vs. Baseline.............................................. 34

Table 7. Knoxville: GS-IHP HVAC/WH energy cost savings $(8 / 18 / 15-8 / 18 / 16)$...................................... 36

Table 8. Oklahoma City: SH performance comparison, IHP vs. Baseline RTU/HP .................................... 38

Table 9. Oklahoma City: SC cooling performance comparison, IHP vs. Baseline RTU/HP .......................... 39

Table 10. Oklahoma City: WH performance comparison, IHP vs. Baseline RTU/HP ............................... 40

Table 11. Oklahoma City: Approximate overall average GS-IHP COPs by operation mode .......................40

Table 12. Oklahoma City: Peak hourly kW demand by month, GS-IHP vs. Baseline ................................ 41






\section{Executive Summary}

Reducing energy consumption in buildings is key to reducing or limiting the negative environmental impacts from the building sector. According to the United States (U.S.) Energy Information Administration (EIA), in 2013, commercial buildings consumed 18.1 quads of primary energy, which was $18.6 \%$ of the total U.S. primary energy consumption. The primary energy consumption in the commercial sector is projected to increase by 2.8 quads from 2013 to 2040 , the second largest increase after the industrial sector. Further space heating, space cooling, and ventilation (HVAC) services accounted for $31 \%$ of the energy consumption in commercial buildings.

Small commercial buildings ( $\leq 10,000 \mathrm{ft}^{2}$ floor space) represent about $21 \%$ of the commercial floor space in the United States. Many such buildings (and defined spaces within larger commercial and institutional buildings) also have significant domestic hot water (DHW) loads, such as restaurants, laundry facilities, health \& fitness centers, etc. The all-electric subset of small commercial buildings consumes approximately 0.160 Quads of primary electricity energy annually for HVAC and WH services.

More than half of U.S. commercial building space HVAC needs are provided by packaged HVAC equipment, mostly rooftop units (RTU; cooling only or heat pump types) with less than 50 tons of cooling capacity. RTUs are popular because they are inexpensive, provide zonal control, are easy to install, and can be serviced without disrupting occupants. Given their advantages, their large market share will likely continue. DHW loads in small commercial buildings are predominantly met by either electric or gas storage water heaters (WH).

Today's RTUs are inefficient for a host of reasons. Many are oversized to handle peak ambient temperatures. Capacity is also wasted by over-drying indoor air in dry climates. Single-speed blowers run for ventilation during all occupied hours, using about half of annual rooftop unit energy. Improving their operational efficiency is essential for enhancing overall commercial building energy performance.

Conventional storage WHs, particularly electric WHs, are approaching thermodynamic limits to their efficiency potential. Storage WHs of the type used in small commercial buildings are subject to Department of Energy (DOE) minimum efficiency requirements. For instance, 50 gallon electric WHs manufactured after April 15, 2015 must have an energy factor (EF, an annual efficiency metric) of $\geq 0.94$. Significant increases in WH efficiency will need to come from use of heat pumping technologies; either combined or integrated heat pumps (IHP) or standalone heat pump water heaters (HPWH).

ClimateMaster, Inc. (CM) and Oak Ridge National Laboratory (ORNL) jointly developed a new, highly efficient electric integrated HVAC and water heating (WH) system - the ground-source integrated heat pump (GS-IHP). The new GS-IHP system is a combination of a very highly efficient variable-speed (VS) water-source heat pump (WSHP) capable of space heating and cooling and domestic water heating 
coupled to a geothermal energy source/sink. Most often the geothermal source/sink is a closed-loop ground heat exchanger (GHX loop). The GS-IHP system was developed primarily for residential buildings and is expected to reduce space heating/cooling energy use by $\geq 50 \%$ and WH energy use by $\geq 75 \%$ for that application compared to minimum efficiency electric heat pump and WH systems. GSIHPs are estimated to have the potential to achieve $\geq 45 \%$ overall energy savings for small commercial buildings with similar building load profiles (e.g., relatively large DHW loads coincident with space heating and cooling loads). They could also reduce peak electric demand by $40 \%$ or more compared to the all-electric baseline system, depending on how coincident the peak air-conditioning and DHW loads are, enabling reduced electric demand charges. Reduced electricity consumption would also have other benefits, such as lower $\mathrm{NO}_{\mathrm{x}}$ and $\mathrm{CO}_{2}$ emissions, and reduced water consumption.

Energy savings are achieved primarily by 1 ) use of the ground vs. outdoor air as the energy source/sink, 2 ) very efficient hot water production, and 3 ) its capacity modulation capability for space heating ( $\mathrm{SH}$ ), space cooling (SC) and WH. During most of the year and particularly during the peak HVAC load months the ground temperature is more favorable for heat pump operation than the outdoor air resulting in higher efficiency operation for the system. The system can meet DHW loads on demand year-round at heat pump COPs (2.5-3.0 or more), much higher than the maximum overall COP of $\sim 0.9-0.95$ that standard electric storage WHs can achieve. When space cooling and DHW demands coincide the GS-IHP system can meet both simultaneously at even higher COPs (5.0 or more). Compared to the single-speed electric RTU baseline, the VS capability of the GS-IHP system allows it to meet off-peak space conditioning (and DHW) demands at much increased efficiency and much reduced electric kW demand. Peak electricity demand is reduced by the same mechanisms.

Even with all these benefits, adoption has been limited due to (1) awareness of the technology which was only recently commercialized (2012) and (2) uncertainty about the relative costs and benefits. This project has attempted to address these challenges by (1) quantifying the environmental and energy impacts and costs of the GS-IHP compared to a conventional electric RTU/heat pump and WH; and (2) disseminating this information through DOE Commercial Building Integration (CBI) strategic deployment. By providing funds for this field demonstration, DOE aids in increasing awareness of the energy savings benefits of GS-IHP technology to building owners.

A site selection evaluation was performed to identify suitable commercial building applications based on the HVAC and DHW load requirements. Based on the evaluation, $\mathrm{CM}$ in collaboration with ORNL selected two sites. The first was a commercial kitchen attached to a day care facility located in a large church building in Knoxville, TN (mixed-humid climate zone). The second is a homeless shelter dormitory type building ( $~ 8,000 \mathrm{ft}^{2}$ total area) in Oklahoma City, OK (warm-humid climate zone). CM installed GS-IHP systems at both sites. At the Knoxville site the GS-IHP provided HVAC and DHW services for a $463 \mathrm{ft}^{2}$ commercial kitchen and an adjoining $60 \mathrm{ft}^{2}$ pantry. The occupancy schedule is from 8:00 am to 5:00 pm Monday through Friday. The Oklahoma installation includes two GS-IHP systems each providing HVAC/WH to 10 residential units (total of $\sim 2500 \mathrm{ft}^{2}$ each). Two other (non IHP) ground source 
heat pumps provide HVAC for common areas of the building. All four heat pump systems are connected to a common GHX loop. In addition the two IHP system HW tanks were connected to a common building HW distribution that included a recirculating loop (to minimize wait time for HW at the individual residential unit fixtures). Only one of the GS-IHPs was instrumented for detailed monitoring. The residential areas of the building are occupied $24 / 7$.

A data acquisition (DAQ) system was designed and installed at both sites. Due to construction delays at the Oklahoma site, DAQ installation there was delayed until January 2016. The DAQ system at the Knoxville site has been collecting data continuously since August 18, 2015. Partial data collection began at the Oklahoma City site on January 31, 2016 enabling evaluation of the SH performance from that date through April 2016. However, the flowmeter necessary for detailed measurement of the water heating performance was lost during initial DAQ installation and it was April before a replacement could be procured and installed. Full data collection has been underway in Oklahoma City since May, 2016 enabling evaluation of the WH and SC performance for a multi-family type application.

For the 2015/2016 test year, the Knoxville site GS-IHP provided $54.6 \%$ total source energy savings compared to a baseline electric RTU/heat pump and electric WH. Peak demand savings ranged from $54 \%$ to $78 \%$ per month. Energy cost savings of $64 \%$ were achieved, with about $65 \%$ due to lower demand charges. Carbon emission savings of $\sim 2.45$ metric tons were achieved as well. If trading for carbon credits ever becomes a reality, additional cost savings would be realized. These savings significantly exceeded the project technical performance goal of $\geq 45 \%$ energy and carbon emission reductions. For this site, no SH loads were experienced; only SC and WH operation was required for the entire test year.

For the Oklahoma City site delays in completing installation of the DAQ system prevented collection of a full year of performance data. However enough data was obtained to allow a reasonable estimate of $\mathrm{SH}, \mathrm{SC}$, and $\mathrm{WH}$ energy savings and efficiency vs. the baseline system.

- $\mathrm{SH}$ : total energy savings of $\sim 753 \mathrm{kWh}(\sim 52 \%)$ and average COP of $\sim 4.9$ (61.7 days data)

- SC: total energy savings of $\sim 18475 \mathrm{kWh}(\sim 50 \%)$ and average COP of $\sim 6.9$ (117.6 days data)

- WH: total energy savings of $\sim 2293 \mathrm{kWh}$ ( 78\%) and average COP of $\sim 4.4$ (109.6 days data) Over the actual monitoring period, the GS-IHP at the site demonstrated total site electricity savings of $\sim 4890 \mathrm{kWh}(\sim 60 \%)$ and carbon emission savings of $\sim 3.47$ metric tons, greatly exceeding the project technical goal. Assuming that the daily average loads and COPs above are the same for the balance of the year for each mode it is estimated that total annual energy savings would be $\sim 12,460 \mathrm{kWh}$ with carbon emission savings of $\sim 8.6$ metric tons. Note that these numbers can be assumed to be double ( $\sim 24,900 \mathrm{kWh}$ and $\sim 17.2$ metric tons) since the shelter building had two GS-IHP units (the second unit was not monitored). The WH savings indicated were estimated assuming that the tank and line heat losses at Oklahoma City were the same as those measured at the Knoxville site due to problems experienced with the building side water flow instrumentation at the homeless shelter. The assumption is considered to be conservative because the HW loads at the homeless shelter were larger and more 
continuous than those at the daycare center kitchen in Knoxville; this would tend to make the tank and connecting line standby losses at the Oklahoma City site a smaller fraction of the total WH delivered by the IHP.

If deployed widely, GS-IHPs would significantly decrease energy consumption, energy costs, and emissions related to space conditioning and water heating for small commercial buildings and individual commercial building spaces having a good balance between total DHW loads and HVAC loads. Opportunities for deployment include new construction as well as replacements for failing equipment. Applied nationally to all appropriate commercial building spaces, GS-IHPs could save 0.084 quads of source energy vs. a 13 SEER RTU/heat pump and electric WH baseline.

This field study successfully demonstrated the energy savings, environmental savings, and operational benefits of the GS-IHP technology for small commercial building applications. The two demonstration systems significantly exceeded the project technical objectives of $>45 \%$ energy and carbon emission savings ( $>50 \%$ at both sites). Best applications of the GS-IHP system are buildings or specific small zones of buildings that have high hot water loads coincident with high space cooling loads. These particular demonstration sites allowed the GS-IHP to take advantage of its combined SC+WH mode featuring fairly extensive recovery of the normally wasted system condenser heat for water heating.

The actual utility bill savings for a building owner will depend on a number of factors, most notably the building's particular load profile, climate region and regional utility rates. Payback analyses were conducted for the Knoxville site system based on the annual energy savings demonstrated. The specific site conditions (limited area, local regulations, etc.) caused drilling costs to be about 3 times higher than typical for the area. For the actual GHX cost, simple payback vs. the baseline RTU/HP/electric WH system was $>30$ years. With more typical GHX costs for the area the payback would be approximately 13 years. For a "mature market" cost assumption based on experience in Oklahoma for a large number of installations the payback drops to 8 years, still likely higher than acceptable for most commercial building owners. Assuming an alternative GHX financing option where the local utility (or other entity) installed and owned the GHX loop (e.g., under an energy savings performance contract or other arrangement, etc.) and amortized the cost via a surcharge on the electric bill were available, payback could be reduced to $<1$ year.

The economics of GS-IHPs will vary from site to site for several reasons, including:

- Regional differences in drilling costs, local site conditions and requirements, and financing options can cause the GHX loop installation costs to vary over a wide range even within a given region. Where local site conditions are unfavorable (restricted area, local permitting/regulation restrictions, etc. as experienced at the Knoxville site) GHX installation costs can be prohibitive 
- Local electricity rate structures may limit the operating cost savings achievable, leading to higher payback periods.

Increasing the adoption of high-efficiency integrated HVAC/WH systems like the GS-IHP will require a change in the way HVAC contractors, design engineers, and building owners and operators consider them due to their increased installation cost. Raising awareness of the availability and the potential lifetime energy savings of GS-IHPs may encourage more industry professionals to evaluate them for their buildings, and determine whether the systems offer an acceptable payback based on climate, operations, building design, etc. Additionally, system designers have difficulty using popular building modeling tools to evaluate nonconventional equipment.

The following actions are recommended for promoting adoption of GS-IHP technology, including:

For Developers of Building Energy Modeling Tools:

- Design specific equipment modules for GS-IHP and include as an option within the modeling software

For DOE and Other Efficiency Organizations:

- Facilitate quick energy savings calculations by developing a simple set of regional climate maps estimating equipment runtimes for different scenarios

- Develop best practice guides based on evaluations against different baseline equipment and building types.

For Electric Utilities:

- Educate commercial customers on the life-cycle cost of GS-IHP technologies and include them in available grant, incentive, or financing programs.

For Local/State Government Agencies, Electric Utilities, other Efficiency Organizations:

- Consider promoting and/or establishing specific financing options for GHX loops for commercial customers

- Consider promoting and/or establishing incentives for GS-IHP systems for commercial customers 


\section{Introduction}

\section{A. Problem Statement}

Reducing energy consumption in buildings is key to reducing or limiting the negative environmental impacts from the building sector. According to the United States (U.S.) Energy Information Administration (EIA), in 2012, commercial buildings consumed 18.1 quads of primary energy, which was $18.6 \%$ of the total U.S. primary energy consumption. ${ }^{1}$ The primary energy consumption in the commercial sector is projected to increase by 2.8 quads from 2013 to 2040, the second largest increase after the industrial sector. ${ }^{2}$ Further space heating, space cooling, and ventilation (HVAC) services accounted for $31 \%$ of the energy consumption in commercial buildings. ${ }^{3}$ Small commercial buildings ( $\leq 10,000 \mathrm{ft}^{2}$ floor space) represent about $21 \%$ of the commercial floor space in the United States. ${ }^{4}$ Many such buildings (and defined spaces within larger commercial and institutional buildings) also have significant domestic hot water (DHW) loads, such as restaurants, laundry facilities, health \& fitness centers, etc. The all-electric subset of small commercial buildings consumes approximately 0.160 Quads of primary electricity energy annually for HVAC and WH services. ${ }^{5}$

More than half of U.S. commercial building space is cooled by packaged HVAC equipment, most of which are rooftop units with less than 50 tons of cooling capacity. ${ }^{6}$ Existing rooftop HVAC units consume more than $1.3 \%$ of total U.S. energy annually. Rooftop units are popular because they are inexpensive, provide zonal control, are easy to install, and can be serviced without disrupting occupants. Given their advantages, their large market share will likely continue.

Today's RTUs are inefficient for a host of reasons. Many are oversized to handle peak ambient temperatures. Undersized/dirty evaporator coils reduce compressor efficiency. Capacity is also wasted by over-drying indoor air in dry climates. Single-speed blowers run for ventilation during all occupied

\footnotetext{
${ }^{1}$ U.S. Energy Information Administration, Annual Energy Outlook 2015, available online at http://www.eia.gov/forecasts/aeo

${ }^{2}$ U.S. Energy Information Administration, Annual Energy Outlook 2015, available online at http://www.eia.gov/forecasts/aeo

${ }^{3}$ U.S. Energy Information Administration, Annual Energy Outlook 2015, available online at http://www.eia.gov/forecasts/aeo

${ }^{4}$ EIA, CBECS 2003 Table C1, the percent commercial floor space in buildings $\leq 10,000 \mathrm{ft}^{2}$ (total floor space in buildings $\leq 10,000 \mathrm{ft}^{2} /$ total building floor space), http://www.eia.gov/consumption/commercial/data/archive/cbecs/cbecs2003/detailed tables_2003/2003set9/20 $03 \mathrm{html} / \mathrm{c1}$.html

${ }^{5}$ EIA, CBECS 2003 Table E3, electricity consumption by end use for non-mall buildings, http://www.eia.gov/consumption/commercial/data/archive/cbecs/cbecs2003/detailed tables 2003/2003set19/2 $003 \mathrm{html} / \mathrm{e} 03 . \mathrm{html}$

${ }^{6}$ EIA (US Energy Information Administration), 2015. 2012 Commercial Buildings Energy Consumption Survey (CBECS), Tables B1 and B2. http://www.eia.gov/consumption/commercial/data/2012/\#summary (accessed September 2015).
} 
hours, using about half of annual rooftop unit energy. Improving their operational efficiency is essential for enhancing overall commercial building energy performance.

Conventional storage WHs particularly electric WHs are approaching thermodynamic limits to their efficiency potential. Storage WHs of the type used in small commercial buildings are subject to DOE minimum efficiency requirements. For instance, a 50 gallon electric WH must have an energy factor (EF, an annual efficiency metric) of $\geq 0.94$. Significant increases in $\mathrm{WH}$ efficiency will need to come from use of heat pumping technologies; either combined or integrated heat pumps (IHP) or standalone heat pump water heaters (HPWH).

ClimateMaster, Inc. (CM) and Oak Ridge National Laboratory (ORNL) jointly developed a new, highly efficient electric integrated HVAC and water heating (WH) system - the ground-source integrated heat pump (GS-IHP). The new GS-IHP system is a combination of a very highly efficient variable-speed (VS) water-source heat pump (WSHP) capable of space heating and cooling and domestic water heating coupled to a geothermal energy source/sink. Most often the geothermal source/sink is a closed-loop ground heat exchanger (GHX loop).

The WSHP unit was tested at Air-conditioning, Heating, and Refrigeration Institute (AHRI) ground loop heat pump (GLHP) conditions ${ }^{7}$ and achieved the highest rated efficiencies of any commercially available WSHP unit at the time of its initial commercial launch in 2012 - heating coefficients of performance (COP) of 5.1 and 3.3 at minimum and maximum speeds, respectively, and cooling energy efficiency ratios (EER) of 45.1 and 21.6 at min and max speeds for the nominal $4-5$ ton capacity units used at the two field sites described in this report. ${ }^{8} \mathrm{CM}$ also produces a smaller, 2-2.5 ton nominal capacity unit with slightly higher efficiencies at maximum compressor speeds -3.6 COP and 24.3 EER. Because tests at fixed conditions do not represent the "true" seasonal energy efficiency, field tests and demonstrations are needed to show the potential savings potential of the GS-IHP. Field demonstrations provide performance comparisons in "real" conditions and allow for: 1) comparison of annual energy savings of the GS-IHP to a standard efficiency electric rooftop unit heat pump (RTU/heat pump) and electric $\mathrm{WH} ; 2$ ) identification of non- performance related issues, such as maintenance requirements; and 3 ) capturing lessons learned and how-to guidance in a concise case study for market deployment.

\section{B. Opportunity}

The GS-IHP system was developed primarily for residential buildings and is expected to reduce space heating/cooling energy use by $\geq 50 \%$ and $\mathrm{WH}$ energy use by $\geq 75 \%$ for that application compared to

\footnotetext{
${ }^{7}$ Air-conditioning, Heating, and Refrigeration Institute, ANSI/AHRI/ASHRAE/ISO Standard 13256-1, "Water-to-Air and Brine-to-Air Heat Pumps - Testing and Rating for Performance," 1998.

${ }^{8}$ ClimateMaster catalog for Trilogy Q-mode (QE) series water source heat pump products, September 2014.
} 
minimum efficiency electric heat pump and WH systems. ${ }^{9}$ GS-IHPs are estimated to have the potential to achieve $\geq 45 \%$ overall energy savings for small commercial buildings or special purpose spaces within larger buildings with similar building load profiles (restaurants, commercial/institutional building kitchen facilities, hotel/motel/dormitory type buildings, laundry facilities, health/fitness centers, etc.). They could also reduce peak electric demand by $40 \%$ or more compared to the baseline electric system, depending on how coincident the peak air-conditioning and WH loads are, enabling reduced electric demand charges. Reduced electricity consumption would also have other benefits for power plants, such as lower $\mathrm{NO}_{x}$ and $\mathrm{CO}_{2}$ emissions and reduced cooling water consumption. Even with all these benefits however, adoption has been limited due to (1) awareness of the technology which was only recently commercialized (2012) and (2) uncertainty about the relative costs and benefits. This project attempts to address these challenges by (1) quantifying the energy savings and costs of the GS-IHP compared to the minimum efficiency electric baseline system; (2) disseminating this information through strategic deployment channels, and (3) encouraging adoption of GS-IHPs that provide greater energy savings so that building owners, managers and developers can make more informed choices.

Energy savings are achieved primarily by very efficient hot water production and its capacity modulation capability for space conditioning and WH. The system can meet WH loads on demand year-round at heat pump COPs (2.5-3.0 or more), much higher than the maximum overall COP of 0.9-0.95 that standard electric storage WHs can achieve. Additionally, coincident WH and space cooling demands can be met simultaneously at even higher COPs (5.0 or more). Compared to the single-speed electric RTU baseline, the VS capability of the GS-IHP system allows it to meet part-load space conditioning (and WH) demands at much increased efficiency and much reduced electric $\mathrm{kW}$ demand. Peak electricity demand is reduced by the same mechanisms.

\section{Technical Objectives}

The technical objective of this project is to demonstrate the capability of the new GS-IHP system to reduce overall energy use for space heating, space cooling, and water heating by at least $45 \%$ vs. a conventional electric RTU and electric WH in a light commercial building application. This project supports the DOE-Building Technologies Office (BTO) goals of reducing HVAC energy use by $20 \%$ and water heating by $60 \%$ by 2030 .

\footnotetext{
${ }^{9}$ Ground-Source Integrated Heat Pump (GS-IHP) Development, CRADA Final Report, CRADE NFE-07-0100, Oak Ridge National Laboratory, ORNL/TM-2013/194, May 2013.
} 


\section{Technology Description}

The demonstrated GS-IHP system is comprised of a nominal 4-5 ton (cooling) WSHP packaged unit coupled to an external geothermal source/sink system and a domestic hot water (DHW) storage tank. For the demonstration systems in this study the geothermal system was a closed-loop ground heat exchanger (GHX loop). Other geothermal source/sink systems are possible as well - e.g., closed-loop heat exchanger submerged in a pond, lake, or river; etc. The WSHP package was CM's Trilogy $45^{\circledR}$ Qmode ${ }^{\circledR}$ IHP product (http://www.climatemaster.com/residential/geothermal-heat-pumps-2/trilogy/ and http://www.climatemaster.com/residential/trilogy/ge/). Table 1 summarizes the Trilogy/GS-IHP system rated/design performance compared to that of a conventional electric RTU/heat pump with a conventional electric storage water heater $(\mathrm{WH})$.

The Trilogy WSHP features a variable-speed (VS) compressor along with a VS blower for indoor air circulation and VS pumps for GHX loop and DHW loop circulation. The system provides variable space cooling, space heating, and water heating capacity as needed by modulating over set point temperature ranges. Four different operating modes are available as listed below:

- Space cooling, or SC (factory set at $1 \frac{1}{2}$ to 4 tons for 4 -ton size unit; installer adjustable to maximum 5 ton capacity)

- Space heating, or SH ( $1 \frac{1}{2}$ to 5 tons for 4-ton size unit)

- Combined WH plus space cooling, or SC+WH

- Dedicated water heating year-round, or DWH

In addition, the VS compressor and blower allow the unit to increase/decrease dehumidification (moisture removal) capacity as needed in response to space $\mathrm{RH}$ level when in $\mathrm{SC}$ modes to maintain comfort levels in the conditioned without sacrificing efficiency. Similarly the air delivery temperature can be adjusted as needed in SH mode. Compact HX designs are used for the air/refrigerant space heating/cooling coil and the GHX loop/refrigerant and hot water/refrigerant coils. This reduces the required system refrigerant charge and associated environmental risks.

The Trilogy systems include a "smart" hot water tank (HW) which includes electric elements for back-up or emergency water heating and HW fittings to minimize mixing of tank water during heat pump WH operation in order to maintain tank stratification. This helps ensure that the hottest water stays at the top of the tank and ready for use by the occupants. Tank controls are integrated with the heat pump unit controls. ${ }^{10}$

${ }^{10}$ ClimateMaster, Inc. product brochure, “Trilogy ${ }^{\circledR} 45$ Geothermal Systems," March 2015. 
Table 1. Summary of GS-IHP versus conventional RTU + Electric Storage WH

\begin{tabular}{|c|c|c|}
\hline & Base (electric RTU/heat pump \& WH) & GS-IHP \\
\hline Compressor/number & Scroll/1-speed & Scroll/variable speed \\
\hline Refrigerant type & R410A & R410A \\
\hline Design Cooling rating & $48,000 \mathrm{Btu} / \mathrm{hr}$ at $95^{\circ} \mathrm{F}$ outdoor temp $\mathrm{a}^{\mathrm{a}}$ & $\begin{array}{l}\text { 18,000 Btu/hr @ min speed }{ }^{b} \\
48,000 \text { Btu/hr @ max speed }\end{array}$ \\
\hline Design Heating rating & $\begin{array}{l}45,000 \mathrm{Btu} / \mathrm{hr} \text { at } 47^{\circ} \mathrm{F} \text { outdoor temp } \mathrm{a}^{\mathrm{a}} \\
28,000 \mathrm{Btu} / \mathrm{hr} \text { at } 17^{\circ} \mathrm{F} \text { outdoor temp }\end{array}$ & $\begin{array}{l}\text { 24,000 Btu/hr @ min speed }{ }^{b} \\
60,000 \text { Btu/hr @ max speed }\end{array}$ \\
\hline $\begin{array}{l}\text { Design water heating } \\
\text { capacity; dedicated WH }\end{array}$ & $4.5 \mathrm{~kW}$ (conventional electric WH) & $\begin{array}{l}\sim 28,000 \mathrm{Btu} / \mathrm{hr} \text {, low speed } \\
\sim 40,000 \mathrm{Btu} / \mathrm{h} \text {, high speed } \\
\left(110^{\circ} \mathrm{F} \text { entering HW temp.; } 35-\right. \\
80^{\circ} \mathrm{F} \text { entering water temperature } \\
\text { from GHX loop })^{c}\end{array}$ \\
\hline $\begin{array}{l}\text { Design cooling plus WH } \\
\text { capacity; combined mode }\end{array}$ & na & 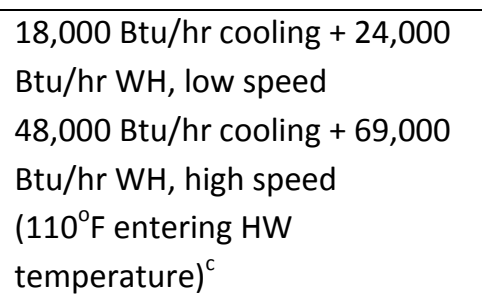 \\
\hline Rated cooling efficiency & $\begin{array}{l}\text { 11.4 EER at } 95^{\circ} \mathrm{F} \text { outdoor temp. } \\
\text { 13.0 SEER }\end{array}$ & $\begin{array}{l}\text { 45.1 EER @ min speed } \\
\text { 21.6 EER @ max speed }\end{array}$ \\
\hline Rated heating efficiency & $\begin{array}{l}3.05 \mathrm{COP} \text { at } 47^{\circ} \mathrm{F} \text { outdoor temperature } \\
2.26 \mathrm{COP} \text { at } 17^{\circ} \mathrm{F} \text { outdoor temperature }\end{array}$ & $\begin{array}{l}5.1 \text { COP @ min speed } \\
3.3 \text { COP @ max speed }\end{array}$ \\
\hline $\begin{array}{l}\text { Design water heating } \\
\text { efficiency; dedicated WH }\end{array}$ & 1.0 COP (conventional electric WH) & $\begin{array}{l}2.5-5.0 \mathrm{COP} \\
\left(110^{\circ} \mathrm{F} \text { entering } \mathrm{HW} \text { temp.; } 35-\right. \\
80^{\circ} \mathrm{F} \text { entering water temperature } \\
\text { from } \mathrm{GHX} \text { loop })^{\mathrm{c}}\end{array}$ \\
\hline $\begin{array}{l}\text { Design cooling plus WH } \\
\text { efficiency; combined mode }\end{array}$ & na & $\begin{array}{l}\text { Up to } 30 \text { EER combined, low } \\
\text { speed } \\
\text { Up to } 19 \text { EER combined, high } \\
\text { speed } \\
\left(110^{\circ} \text { F entering HW temp. }\right)^{c}\end{array}$ \\
\hline Unit dimension (in) & $45 \mathrm{LX} 47 \mathrm{HX} 76 \mathrm{~W}$ & $25.4 \mathrm{LX} 56 \mathrm{HX} 30.6 \mathrm{~W}$ \\
\hline Unit weight & $590 \mathrm{lb}, \mathrm{RTU}$ & $448 \mathrm{lb}$, Trilogy WSHP \\
\hline Electrical & $\begin{array}{l}13.0 \mathrm{~kW}, \mathrm{RTU} \\
4.5 \mathrm{~kW}, \mathrm{WH} \operatorname{tank}\end{array}$ & $\begin{array}{l}8.5 \mathrm{~kW} \text {, heat pump unit } \\
4.5 \mathrm{~kW}, \text { WH tank }\end{array}$ \\
\hline
\end{tabular}

${ }^{a}$ Certified per ANSI/AHRI Standard 210/240

${ }^{b}$ Certified per ANSI/AHRI/ISO/ASHRAE Standard 13256-1. The Trilogy can be adjusted at installation to 5ton maximum cooling capacity as was done at the Oklahoma City site; a 5-ton cooling capacity conventional RTU heat pump was used for the baseline comparisons at that site as noted in later sections of this report.

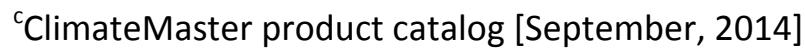




\section{Project Scope}

A new technology (GS-IHP) based on a DOE funded concept development is estimated to reduce both site and source energy consumption for HVAC and water heating (WH) by at least $45 \%$ overall compared to minimum efficiency electric HVAC/WH systems. This would also have other benefits, such as reduced electrical demand and lower $\mathrm{NO}_{\mathrm{x}}$ and $\mathrm{CO}_{2}$ emissions associated with the lower electricity consumption. Even with all these benefits, adoption has been limited due to (1) awareness of the technology which was only recently commercialized (2012) and (2) uncertainty about the relative costs and benefits. This project attempts to address these challenges by (1) quantifying the environmental and energy impacts and costs of the GS-IHP compared to a conventional electric RTU and electric WH; (2) disseminating this information through $\mathrm{CBI}$ strategic deployment, and (3) encouraging adoption of the technology so that building owners, managers and developers can make more informed choices.

This report is not intended to be used as a recommendation for using a GS-IHP based purely on the current results; rather this report emphasizes the potential savings opportunities when favorable conditions exist. When selecting HVAC equipment for particular applications, additional considerations of applicability, installation methods, electricity and gas costs, necessity for water heating, etc., are needed.

\section{Project Approach}

\section{A. Field Site Selection and Installation}

A site selection evaluation was performed to identify suitable commercial building applications based on the HVAC and water heating load requirements. Based on the evaluation, CM in collaboration with ORNL selected two sites. The first was a commercial kitchen attached to a day care facility located in a large church building in Knoxville, TN. Knoxville is located in climate Zone 4A (Mixed-Humid per Figure 1 and Table 2 below). The second is a homeless shelter dormitory type building ( 8,000 $\mathrm{ft}^{2}$ total floor space) in Oklahoma City, OK - climate Zone 3A (Warm-Humid). CM and its subcontractors (City Heat \& Air of Knoxville and Comfortworks, Inc. of Goldsby, OK) designed and installed GS-IHP systems at both sites based on their Trilogy 45 IHP Qmode product. Figures 2-10 provide photos and GHX schematics for the two installations. At the Knoxville site (Figures 2-6) a single GS-IHP provided HVAC and DHW services for the $463 \mathrm{ft}^{2}$ kitchen and adjoining $60 \mathrm{ft}^{2}$ pantry. The occupancy schedule is 8:00 am to 5:00 pm Monday through Friday except for holidays. 




Figure 1. Map of USA climate zones (Source: ANSI/ASHRAE/IESNA Standard 90.1-2007). Stars indicate GS-IHP demonstration site locations

Table 2. Description of USA climate zones (Source: ANSI/ASHRAE/IESNA Standard 90.1-2007)

\begin{tabular}{|c|c|c|}
\hline Zone Number & Name & Thermal Criteria \\
\hline 1 & $\begin{array}{c}\text { Very Hot - Humid (1A), } \\
\text { Dry (1B) }\end{array}$ & $5000<\mathrm{CDD} 10^{\circ} \mathrm{C}$ \\
\hline 2 & Hot - Humid (2A), Dry (2B) & $3500<\mathrm{CDD} 10^{\circ} \mathrm{C} \leq 5000$ \\
\hline $3 \mathrm{~A}$ and $3 \mathrm{~B}$ & Warm - Humid (3A), Dry (3B) & $2500<\mathrm{CDD} 10^{\circ} \mathrm{C} \leq 3500$ \\
\hline $3 \mathrm{C}$ & Warm - Marine & $\begin{array}{c}\mathrm{CDD}^{\circ} 0^{\circ} \mathrm{C} 2500 \mathrm{AND}^{*} \\
\mathrm{HDD} 18^{\circ} \mathrm{C} 2000\end{array}$ \\
\hline $4 A$ and $4 B$ & Mixed - Humid (4A), Dry (4B) & $\begin{array}{l}\mathrm{CDD} 10^{\circ} \mathrm{C} \leq 2500 \mathrm{AND} \\
2000<\mathrm{HDD} 18^{\circ} \mathrm{C} \leq 3000\end{array}$ \\
\hline $4 \mathrm{C}$ & Mixed - Marine & $2000<\mathrm{HDD} 18^{\circ} \mathrm{C} \leq 3000$ \\
\hline $5 \mathrm{~A}, 5 \mathrm{~B}$ and $5 \mathrm{C}$ & Cool-Humid (5A), Dry (5B), Marine (5C) & $3000<\mathrm{HDD} 18^{\circ} \mathrm{C} \leq 4000$ \\
\hline $6 \mathrm{~A}$ and $6 \mathrm{~B}$ & Cold - Humid (6A), Dry (6B) & $4000<\mathrm{HDD} 18^{\circ} \mathrm{C} \leq 5000$ \\
\hline 7 & Very Cold & $5000<\mathrm{HDD} 18^{\circ} \mathrm{C} \leq 7000$ \\
\hline 8 & Subarctic & $7000<\mathrm{HDD} 18^{\circ} \mathrm{C}$ \\
\hline
\end{tabular}

${ }^{*}$ CDD (cooling degree C-days) $\leq 2500$ AND HDD (heating degree-C days) $\leq 2000$ 


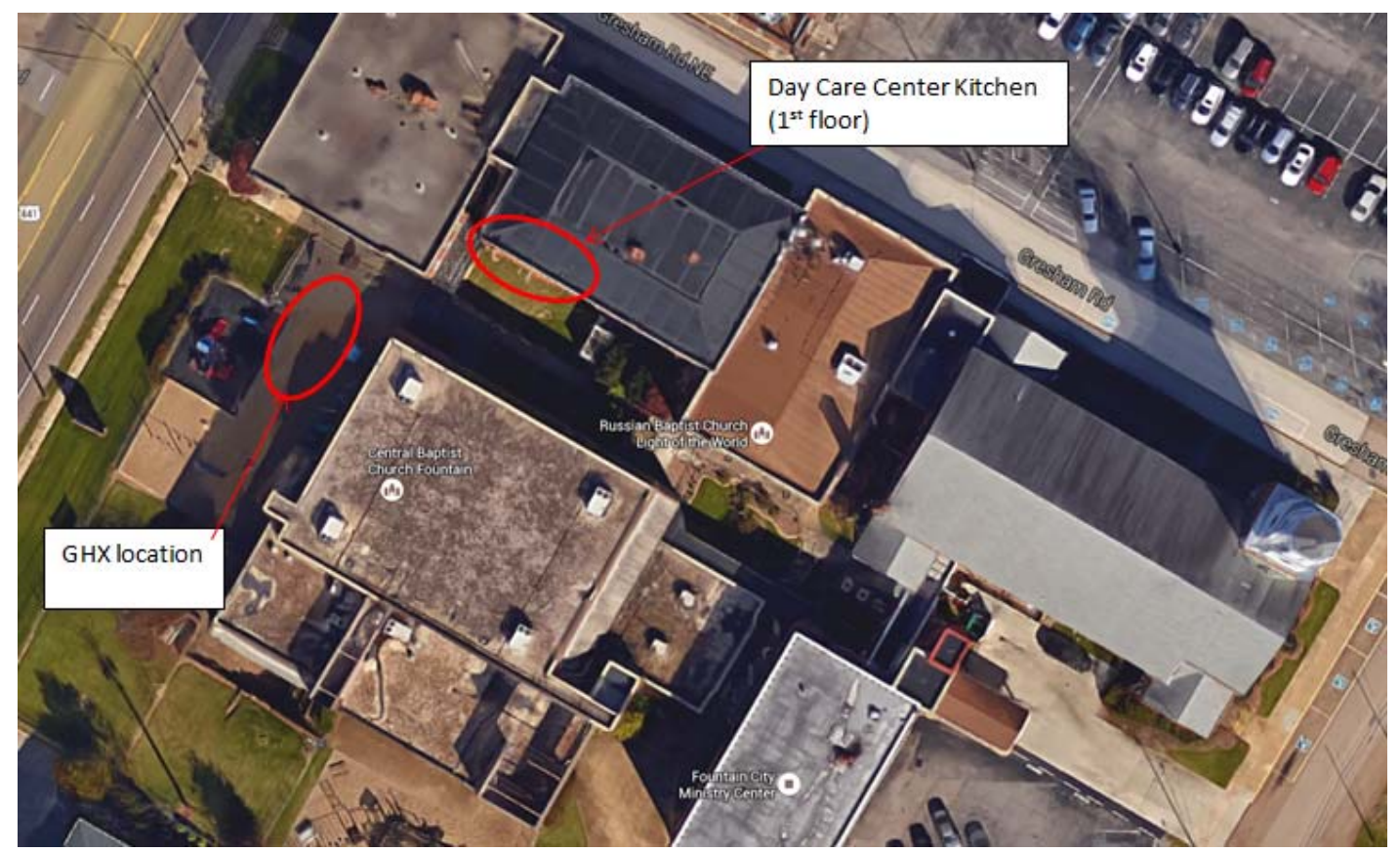

Figure 2. Aerial view of the Knoxville, TN test site (Photo source: Google Maps)

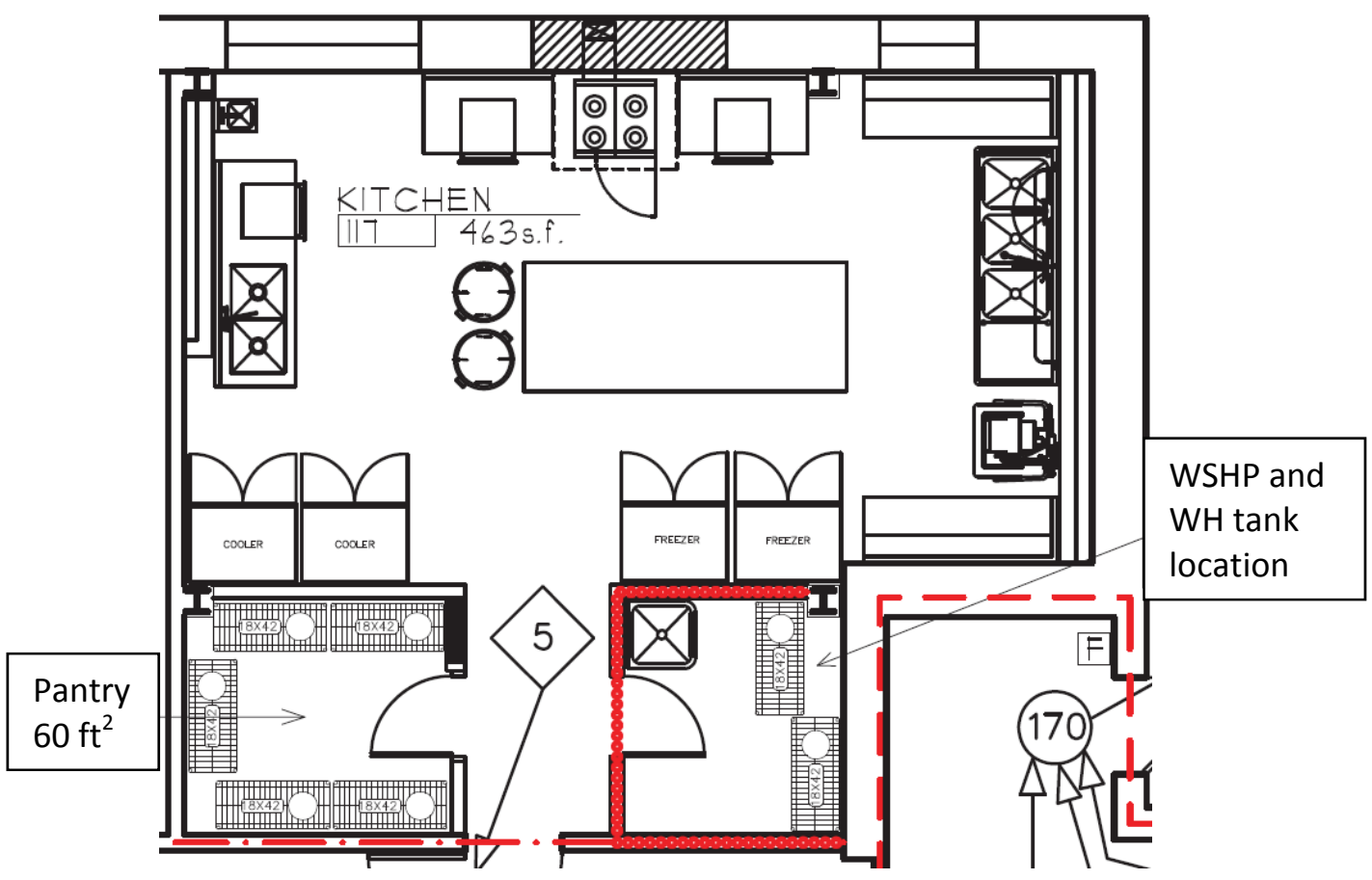

Figure 3. Kitchen floor plan, Knoxville, TN test site 


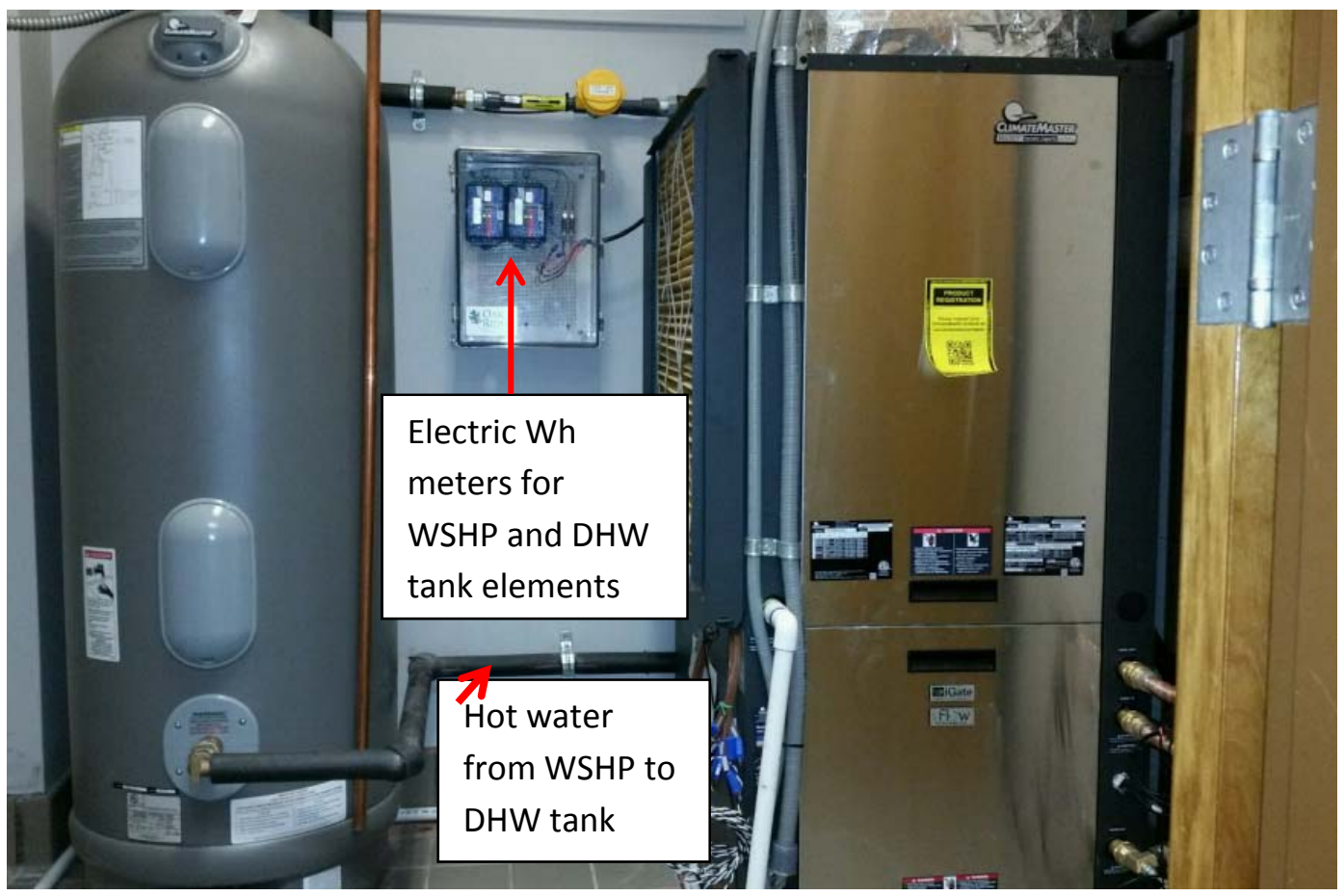

Figure 4. Trilogy WSHP system as installed at the Knoxville, TN test site

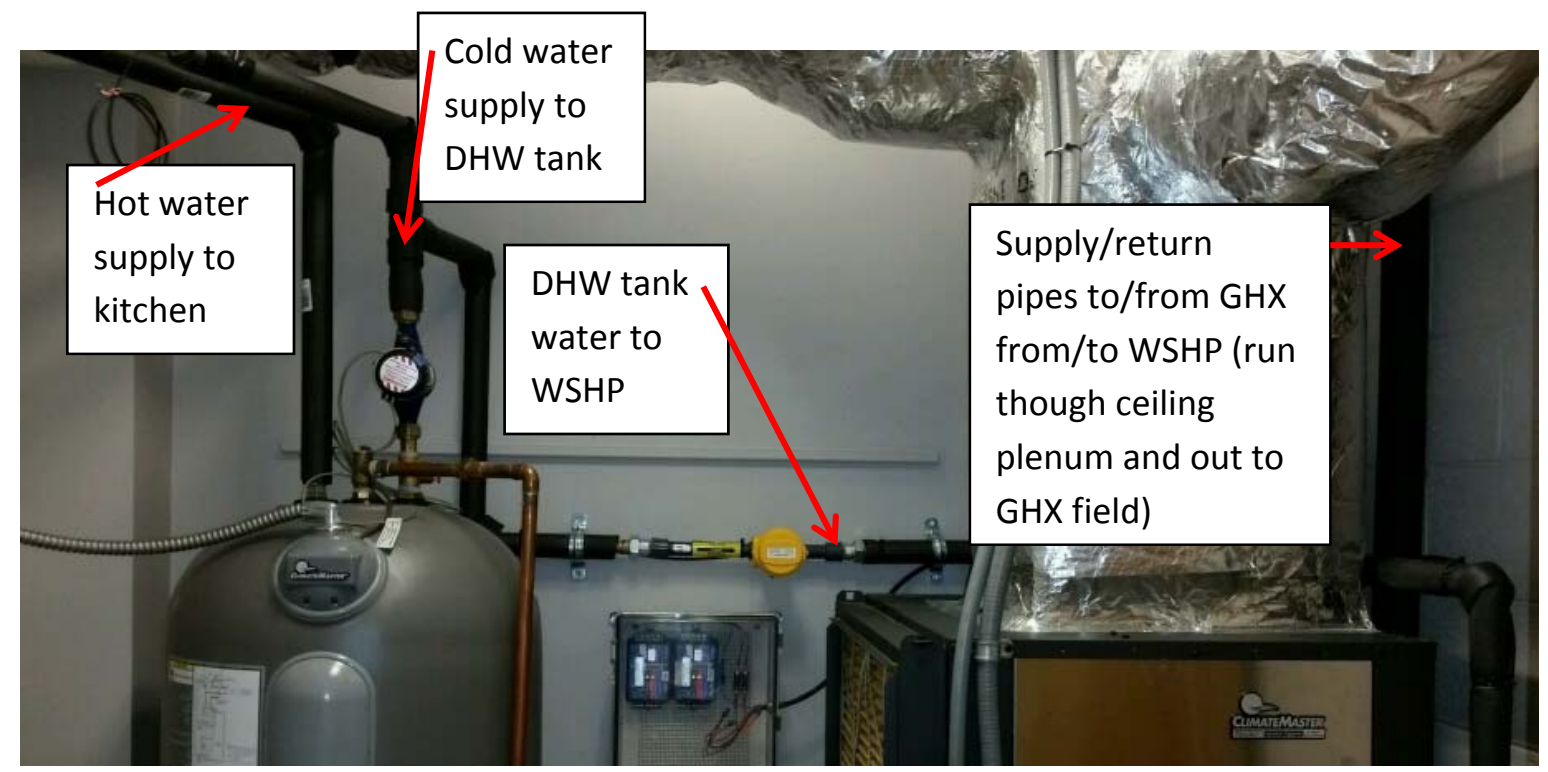

Figure 5. WH piping connections and flowmeters at Knoxville site. 

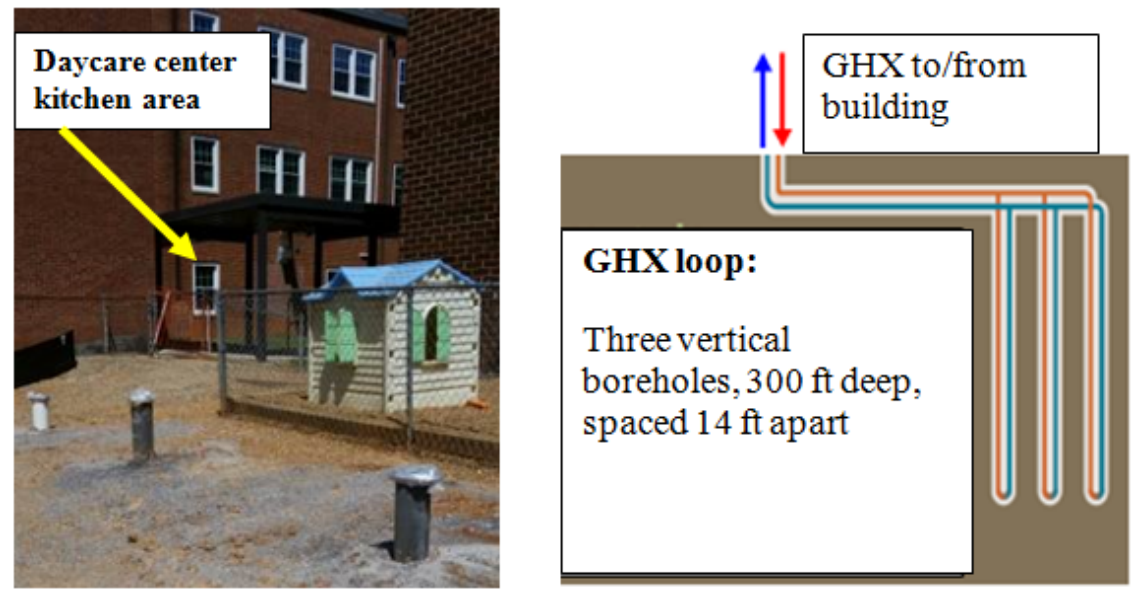

Figure 6. GHX loop location and schematic for Knoxville, TN test site (graphic source: ClimateMaster)

The Oklahoma installation (Figures 7-10) includes two Trilogy-based GS-IHP systems with 105 gallon hot water (HW) tanks each providing HVAC/WH to 10 residential units (total of $\sim 2500 \mathrm{ft}^{2}$ each). Due to the higher peak design cooling loads at this site the Trilogy units were set up during installation to provide maximum cooling capacity of 5 tons $(60,000 \mathrm{Btu} / \mathrm{h}$ ) each. Two other (non IHP) ground source heat pumps provide HVAC for common areas of the building. The total nominal cooling capacity for all four heat pump systems was 18 tons $(216,000 \mathrm{Btu} / \mathrm{h})$ and all are connected to a common GHX loop. Each WSHP unit used its own internal loop circulator pump; no central system pump was used. Only one of the GS-IHPs was instrumented and monitored in detail. The residential areas of the building are occupied $24 / 7$.

The two Trilogy HW tanks are connected to a common building HW distribution system. This system includes a HW recirculation loop to minimize the wait time for $\mathrm{HW}$ at the fixtures in each residential unit; the recirculation pump energy use was not monitored. Only one of the tanks was instrumented to attempt to determine the HW energy delivered to the building HW distribution system.

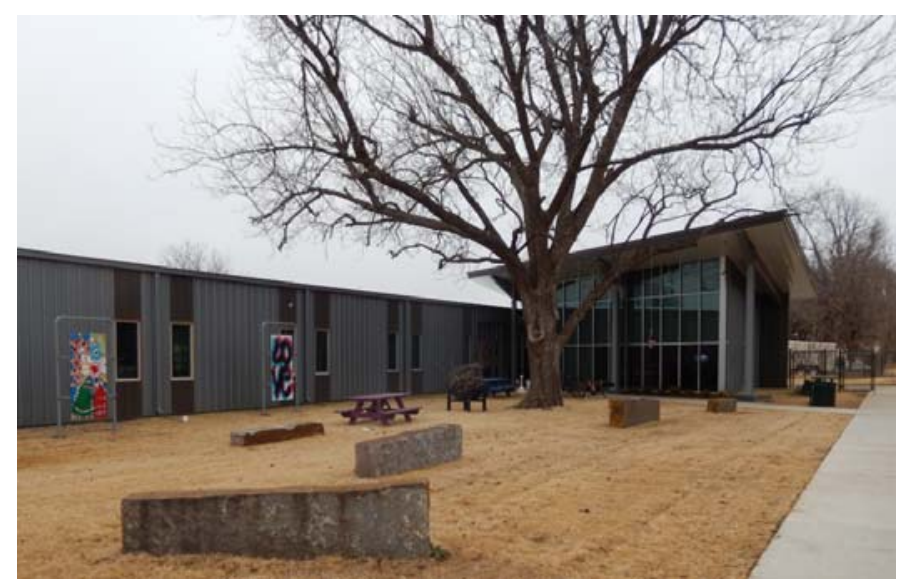

Figure 7. Oklahoma City, OK test site host building 


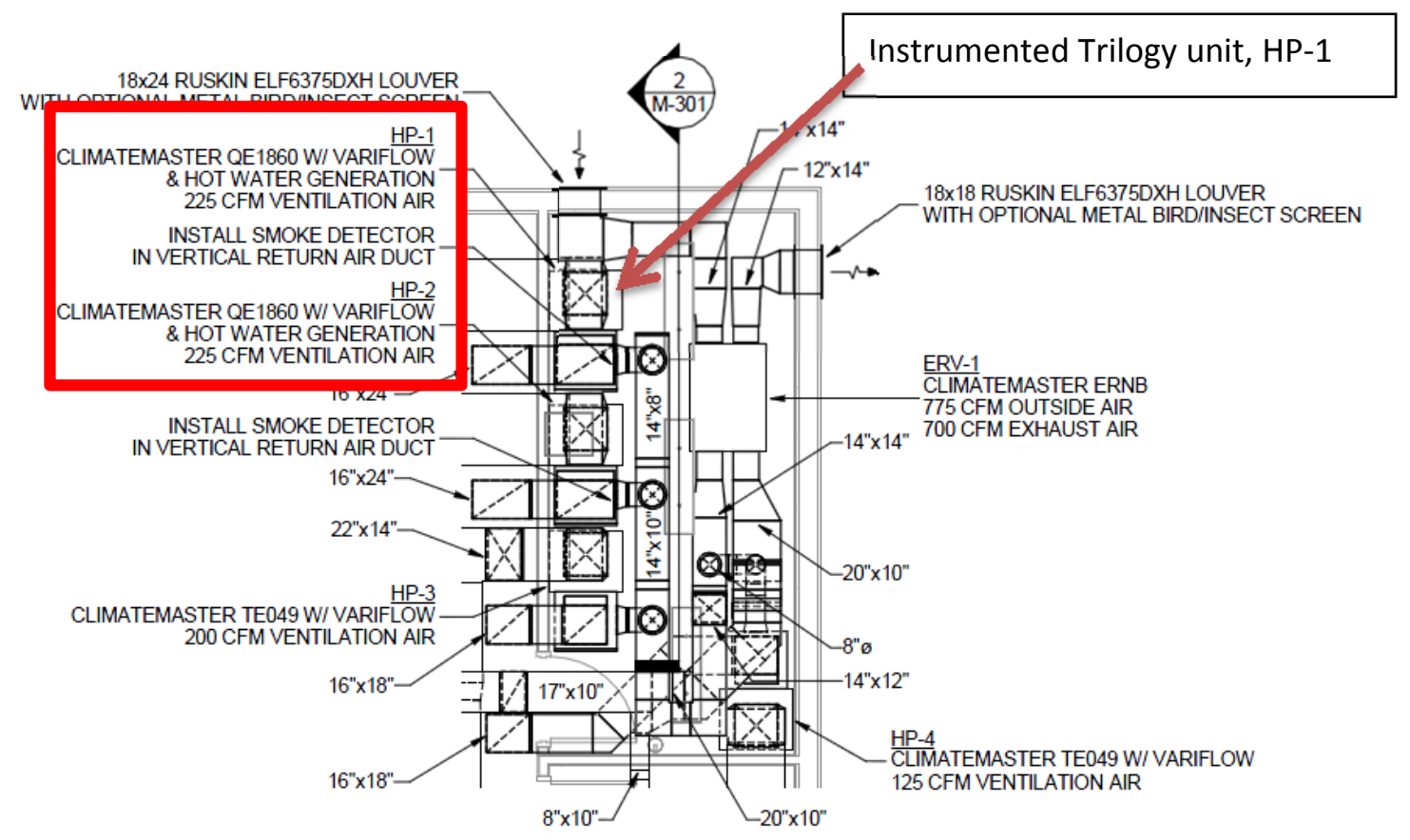

Figure 8. Oklahoma City, OK building mechanical room floor plan; Trilogy units are HP-1 and HP-2 (Source: ClimateMaster)



Figure 9. Oklahoma City host building mechanical room; instrumented Trilogy is on Ih side against back wall; Trilogy HW tanks at right (Source: ClimateMaster) 




Figure 10. GHX loop location and details for Oklahoma City, OK test site (Source: ClimateMaster)

There were strong advocates at both sites to serve as the primary points of contact with access to the space, equipment, and operations. The areas or spaces being considered for demonstration are representative of the conditions and functions for the expected application of the technology.

\section{B. Metering and Monitoring Plan}

The test systems were installed and commissioned to ensure proper operation at both sites. Data acquisition (DAQ) systems were designed and installed at each site. The DAQ system at the Knoxville site began collecting data continuously on August 18, 2015 until the end of the test period with only one 3-day outage. Due to construction delays at the Oklahoma site DAQ installation there was delayed. Partial data monitoring (for SH performance) began there on January 31, 2016. A water flow meter required for monitoring of WH operation was lost during initial DAQ installation and could not be replaced and installed until mid-April. Full data collection, including WH mode operation, has been underway at Oklahoma City since May 19, 2016, but with several outages as noted in Section VI.

Data is collected at 15 second intervals, averaged into one minute intervals, and sent to a remote server at ORNL via the internet. An error analysis of the instrumentation (Table 3) was included to determine the overall sensor accuracy of the data collection. During the collection of data, the GS-IHPs were 
operated as normal with a wall thermostat to control space heating and cooling operation, and a WH tank thermostat to control WH operation.

ORNL pulled the data files from the test sites and stored them on file storage resources at ORNL. The data was subsequently loaded into a searchable database. This facilitates access to the data since it can be queried on any number of constraints (i.e., date ranges, parameter values, etc.) by most data analysis packages. MATLAB and Excel were used to analyze the data for this report.

Table 3. Instrumentation

\begin{tabular}{|c|c|c|c|}
\hline Monitoring point & Manufacturer & Model No. & Error \\
\hline $\begin{array}{l}\text { Trilogy WSHP unit \& WH } \\
\text { tank element energy } \\
\text { consumption }\end{array}$ & $\begin{array}{l}\text { Continental } \\
\text { Control Systems }\end{array}$ & $\begin{array}{l}\text { WattNode models WNC- } \\
\text { 3Y-208-MB and WNB- } \\
\text { 3Y-208-P, respectively }\end{array}$ & $\begin{array}{l} \pm 0.5 \% \mathrm{~W} \text { reading for } 5-100 \% \\
\text { rated current ( } \pm 1 \% \text { of reading } \\
\text { for } 1-5 \% \text { rated current) }\end{array}$ \\
\hline Line voltage & $\begin{array}{l}\text { Continental } \\
\text { Control Systems }\end{array}$ & $\begin{array}{l}\text { WattNode model WNC- } \\
3 Y-208-M B\end{array}$ & $\pm 0.5 \% \mathrm{~V}$ reading \\
\hline $\begin{array}{l}\text { Supply/Return } \\
\text { Temperatures, Trilogy } \\
\text { to/from GHX loop }\end{array}$ & Omega & $\begin{array}{l}\text { PM-1/10-1/8-6-1/8-P-3; } \\
\text { platinum resistance } \\
\text { temperature device } \\
\text { (RTD), immersion }\end{array}$ & $\begin{array}{l} \pm(0.03+0.0005|\mathrm{t}|)^{\circ} \mathrm{C} \text { From } 0 \\
\text { to } 100^{\circ} \mathrm{C}^{\mathrm{a}}\end{array}$ \\
\hline $\begin{array}{l}\text { Supply/discharge } \\
\text { Temperatures, Trilogy } \\
\text { to/from DHW tank }\end{array}$ & Omega & $\begin{array}{l}\text { PM-1/10-1/8-6-1/8-P-3; } \\
\text { platinum RTD, } \\
\text { immersion }\end{array}$ & $\begin{array}{l} \pm(0.03+0.0005 \mathrm{t})^{\circ} \mathrm{C} \text { From } 0 \text { to } \\
100^{\circ} \mathrm{C}^{\mathrm{a}}\end{array}$ \\
\hline $\begin{array}{l}\text { Supply/Return } \\
\text { Temperatures, DHW } \\
\text { tank to/from building } \\
\text { HW distribution network }\end{array}$ & Omega & $\begin{array}{l}\text { PM-1/10-1/8-6-1/8-P-3; } \\
\text { platinum RTD, } \\
\text { immersion type }\end{array}$ & $\begin{array}{l} \pm(0.03+0.0005 \mathrm{t})^{\circ} \mathrm{C} \text { From } 0 \text { to } \\
100^{\circ} \mathrm{C}^{\mathrm{a}}\end{array}$ \\
\hline Flow; GHX loop & Omega & FMG3001-PP & $\pm 0.8 \%, \max ^{\mathrm{b}}(\sim 1-20 \mathrm{gpm})$ \\
\hline Flow, DHW tank loop & Omega & FMG3001-PP & $\pm 0.8 \%, \max ^{b}(\sim 1-10$ gpm) \\
\hline $\begin{array}{l}\text { Flow, building water } \\
\text { supply to DHW tank }\end{array}$ & Omega & FTB8007B-PT & $\pm 1.5 \%(0.22-22 \mathrm{gpm})$ \\
\hline ID space temperature & $\begin{array}{l}\text { Trilogy onboard } \\
\text { sensor }\end{array}$ & $\begin{array}{l}\text { Thermistor included } \\
\text { with CM thermostat }\end{array}$ & $\pm 0.56^{\circ} \mathrm{C}\left( \pm 1.0^{\circ} \mathrm{F}\right)$ \\
\hline ID space RH (\%) & $\begin{array}{l}\text { Trilogy onboard } \\
\text { sensor }\end{array}$ & $\begin{array}{l}\text { Johnson Controls model } \\
\text { HT-6703 }\end{array}$ & $\pm 3 \% \mathrm{RH}$ \\
\hline $\begin{array}{l}\text { WH upper tank wall } \\
\text { temperature }\end{array}$ & $\begin{array}{l}\text { Trilogy onboard } \\
\text { sensor }\end{array}$ & $\begin{array}{l}\text { Thermistor mounted to } \\
\text { WH tank wall }\end{array}$ & $\pm 0.56^{\circ} \mathrm{C}\left( \pm 1.0^{\circ} \mathrm{F}\right)$ \\
\hline $\begin{array}{l}\text { Temperature in/out } \\
\text { Trilogy air coil }\end{array}$ & Omega & Type T TC & 0.75\% Full Scale \\
\hline $\begin{array}{l}\text { RH\% in/out Trilogy air } \\
\text { coil }\end{array}$ & Omega & HX92AC-D & $\begin{array}{l} \pm 2.5 \% \text { RH from } 20 \text { to } 80 \% \mathrm{RH} ; \\
\pm 3.1 \% \mathrm{RH} \text { below } 20 \text { and above } \\
80 \% \mathrm{RH} @ 22^{\circ} \mathrm{C} \text { with temp } \\
\text { coefficient of } \pm 0.1 \% \mathrm{RH} /{ }^{\circ} \mathrm{F} \\
\text { Output }\end{array}$ \\
\hline Ambient Temp & $\begin{array}{l}\text { Local airport } \\
\text { weather data }\end{array}$ & $\begin{array}{l}\text { Ecobee web site } \\
\text { accessed via Trilogy } \\
\text { control system }\end{array}$ & $\mathrm{Na}$ \\
\hline
\end{tabular}

${ }^{a}$ All RTDs underwent 5 point calibration over expected temperature operating range ( 30 to $140{ }^{\circ} \mathrm{F}$ ) against NIST traceable thermometer; linear fit to temperature standard with $\mathrm{R}^{2}$ of 1.000 .

${ }^{\mathrm{b}}$ Results of factory calibration against NIST traceable standard over expected operating flow ranges. 
Figure 11 shows a schematic of the GS-IHP system, including the critical sensor locations.

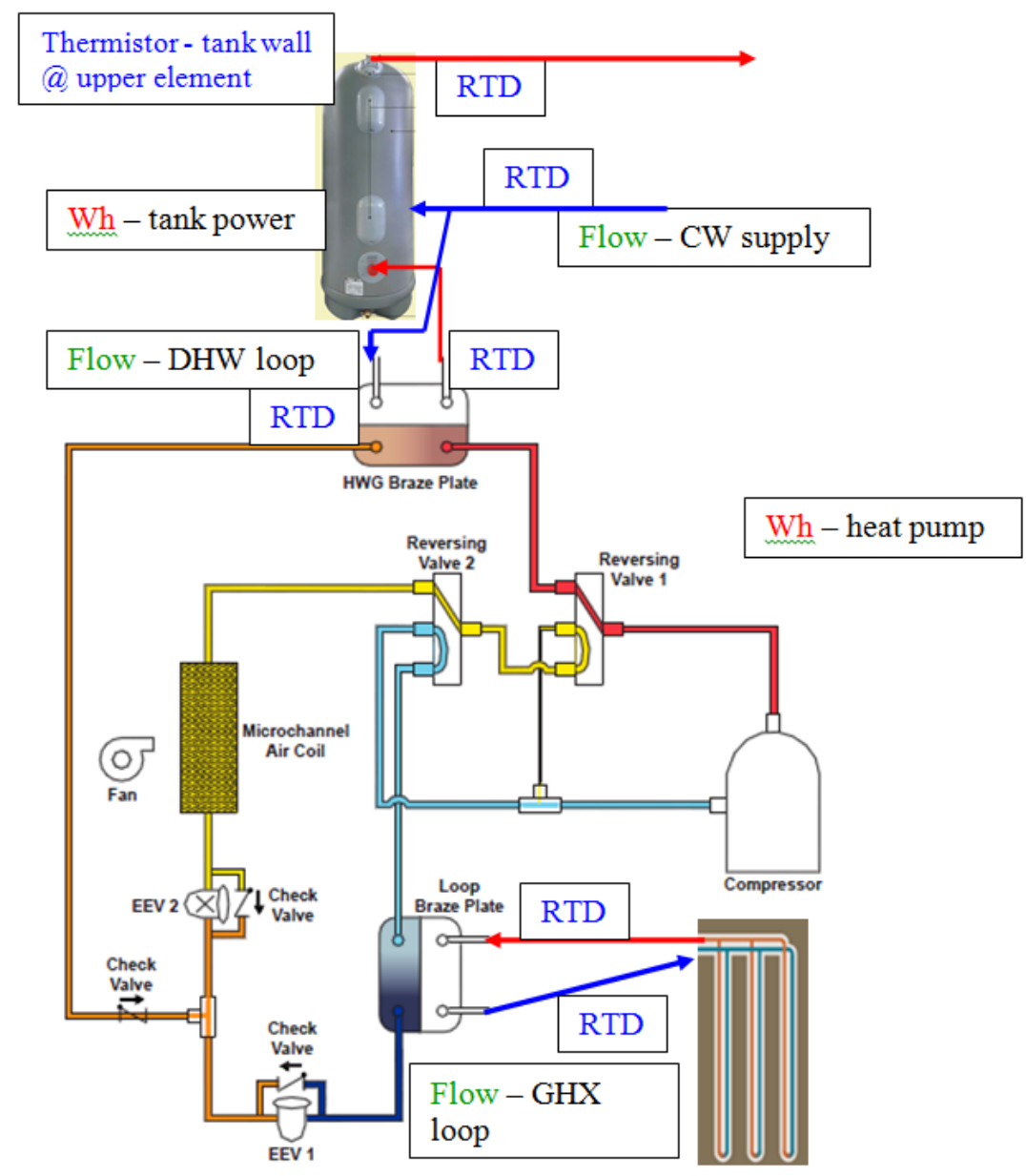

Figure 11. GS-IHP schematic with critical sensor locations (Graphic source: ClimateMaster)

\section{Energy Savings Estimation Approach}

The goal of this demonstration is to estimate the annual energy savings and costs of the GS-IHP technology versus a standard efficiency electric RTU and electric water heater.

The site measured data (loop temperatures and flow rates) are post-processed and used to compute space heating, space cooling, and water heating energy delivered by the GS-IHP for each mode using the equations below. These calculated values are stored along with the measured data for each 15second data scan. 
Space cooling delivered (SC Mode)

$$
Q_{S C}=V_{\text {GroundLoop }} \rho_{\text {GroundLoop }} C_{\text {GroundLoop }}(L W T-E W T)-W_{I H P}
$$

Space cooling delivered (SC+WH Mode)

$$
Q_{S C}=Q_{W H, I H P}-W_{I H P}
$$

Space heating delivered (SH mode)

$$
Q_{S H}=V_{\text {GroundLoop }} \rho_{\text {GroundLoop }} c_{\text {GroundLoop }}(E W T-L W T)+W_{I H P}
$$

Water heating delivered by IHP to the WH tank and connecting lines between tank and IHP (DWH mode)

$$
Q_{W H, I H P}=V_{D H W L o o p} \rho_{D W H L o o p} c_{D W H L o o p}(L D W H T-E D W H T)
$$

Water heating delivered to building

$$
Q_{W H}=V_{H o t} \rho_{H o t} c_{H o t}\left(T_{H o t}-T_{\text {Cold }}\right)
$$

(Note 1:THot was taken to be the maximum of a) the leaving hot water temperature measured by an immersion RTD sensor in the hot water exit line to the building distribution system, or b) the upper tank wall temperature measured by a thermistor located near the upper element. Many of the hot water draws experienced were of such small volumes and short durations that the response time of the RTD was too slow to capture an accurate measure of the leaving hot water temperature.)

(Note 2: In addition it was discovered late in the project that the flowmeter at the Fountain City site providing the $V_{H o t}$ measurement was subject to some flow oscillations in the cold water line. Due to the nature of the meter, these oscillations caused the flow measurement to be higher than the actual flow. This erroneous flow was filtered out of the data by checking the corresponding temperature of the hot water leaving the tank. When the measured flow was caused by oscillations, the hot water temperature sensor was far enough away from the tank that it did not increase in temperature. Any flow data without a corresponding increase in hot water temperature or that was comprised of less than 3 pulses from the flow meter was removed from the data set. This may have inadvertently eliminated some small flow events ( $<0.2$ gallons), so the calculation of the water heating energy delivered to the building is likely conservative. At the Oklahoma City site there was significant uncertainty about where to place the sensor owing to the presence of the HW recirculation system and the fact that there were two IHP systems with water tanks. With the amount of instrumentation budgeted for the project it was not possible to obtain a good measure of the WH energy actually delivered to the building HW distribution system from each individual tank with any confidence. Therefore we decided to make the assumption that the tank and connecting line standby heat losses measured at Knoxville ( $23 \%$ combined) also applied to the Oklahoma City system. This is believed to be a somewhat conservative assumption based on the fact that the IHP in Oklahoma City experienced heavier and more continuous WH loads than did the system in Knoxville. The system in Oklahoma spent an average of $\sim 12 \%$ of its total test period hours in WH modes compared to $<5 \%$ for the Knoxville system. With longer runtimes and heavier WH loads, the HW tank and connecting line standby heat losses should be a smaller fraction of the total load.)

Where -

- $\quad E W T:$ GHX loop fluid temperature entering WSHP (RTD)

- $\quad$ LWT: GHX loop fluid temperature leaving WSHP (RTD) 
- $\quad E D W H T$ : domestic hot water temperature entering WSHP (RTD)

- LDWHT: domestic hot water temperature leaving WSHP (RTD)

- $T_{\text {Cold: }}$ cold water supply temperature to WH tank (RTD)

- $T_{\text {Hot: }}$ hot water temperature leaving WH tank (see parenthetical note above)

- $V$ : fluid flow rate

- $\rho$ : fluid density

- $\quad c$. fluid specific heat

Energy consumption for the GS-IHP is measured directly by two watt-hr meters, one for the Trilogy unit $\left(W_{I H P}\right)$ and one for the WH tank back up elements $\left(W_{\text {tank }}\right)$. For the combined space cooling and water heating mode the energy consumption is apportioned to each output proportional to the output capacity by a data analysis program and stored along with the loads data for each time step. This implicitly assumes that the efficiency, or coefficient of performance (COP) for both SC and WH in the combined mode is the same.

The energy delivery and measured energy use for the GS-IHP in each mode are totaled for each month/season and compared with the estimated energy used by the baseline RTU/electric WH to meet the same loads. The baseline RTU performance use was estimated using performance curves that account for variations in outdoor temperature and humidity, indoor temperature and humidity, time/temperature controlled defrosting, cyclic losses, and supplemental resistance heating. Defrost cycles were assumed to be $5.8 \%$ of the operating time at outdoor temperatures below $40^{\circ} \mathrm{F}$ and the defrost tempering heat energy was equal to the cooling done during the defrost cycle. Note that the measured cooling load was not broken down into sensible and latent parts. Since the GS-IHP varies its VS blower speed (rpm) to adjust the split of sensible and latent cooling required by the space, it is assumed that it delivers the minimum total cooling energy required to maintain comfortable indoor conditions. In contrast, the baseline RTU unit does not have a VS indoor blower and therefore cannot adjust the ratio of sensible and latent cooling delivered. This either results in insufficient latent cooling and discomfort or excess latent cooling and wasted energy. As such, assuming similar comfort levels are maintained by both systems, the SC savings calculated for the GS-IHP over the RTU system are conservative. Energy savings and carbon emission reductions for the GS-IHP are computed as the difference in these values vs. the Baseline.

\section{Cost Savings Approach}

Electricity rates were obtained from the local electric utilities at each demonstration location and used along with the measured energy use of the GS-IHP and the estimated energy use of the baseline system to determine annual energy related costs. for Knoxville, the rate data include both demand charges and hourly usage charges. For Oklahoma, only hourly usage charges were available for residential buildings like the homeless shelter. Annual energy savings for the GS-IHP at each site are estimated based on the energy costs estimated using these rates. GS-IHP system installed cost estimates (high and low) were 
made for the Knoxville site design vs. a baseline RTU/HP and electric WH using high and low estimates for GHX loop installation cost.

\section{E. Installation Cost}

Actual system installation cost data were compiled for each site and are listed below. In addition to the actual cost for Knoxville an assumed "mature market" installation cost estimate was made for use in the payback analysis discussed in this report. Payback estimates (high and low) were made for a GS-IHP system of the Knoxville site design vs. the baseline RTU/HP and electric WH using the range of GS-IHP installation cost estimates below.

The major variable impacting GS-IHP system installation cost is the external geothermal heat source/sink. As noted earlier, in most cases this involves drilling/excavation and installation of a GHX loop (usually of the vertical bore field type). For the Knoxville site, three "out of normal" installation issues were experienced that negatively impacted the actual system costs.

- First and most important were the drilling issues related to the urban location. The majorĔ complication was that provisions had to be made to recover all the drilling cuttings and fluidsĚor "mud" to avoid overloading the nearby city storm sewers. A vacuum pump truck had toĚ accompany the drill rig to the site to accomplish this recovery causing a significant increase inĚ the drilling costs.

- Secondly, space available for the GHX field at the site was relatively tight so a horizontalĚboring machine had to be used to run the GHX header pipes from the GHX field to the building. most cases a much less expensive trenching machine is used to dig a trench for the headers. The space issue also limited the maximum distance between the boreholes to $14 \mathrm{ft}$ instead of CM's normally recommended 20-25 ft spacing. While this did not directly impact installationĚ cost it could potentially impact long term performance if the annual loads on the loop areĚ significantly unbalanced (e.g. annual heat rejection to the ground is much greater than annualě heat extraction).

- Finally, the GHX header piping had to be partly exposed to ambient air. This was because itĚwas not possible to run the headers under the building to the WSHP location next to theĚkitchen facility due to existing underground infrastructure. The header piping had to be run upĚthe outside wall and then through a ceiling plenum above the WSHP (see Figure 12, below, andĚ Figure 5) and added about a day to the installation time. This situation occurs only rarely in theĚ experience of the installing contractors. It also required that an antifreeze solution be addedĚto the water in the GHX loop in early January 2016 to avoid any potential loop freeze problems. This added an estimated $\$ 700$ to the system cost (cost of the antifreeze plus an additional siteĚ visit) and slightly reduces the system performance relative to a water only loop. 
The installing contractor estimated that for a more rural location without all the above complicating factors the GHX install costs could have been reduced by a factor of 2-3. ${ }^{11}$

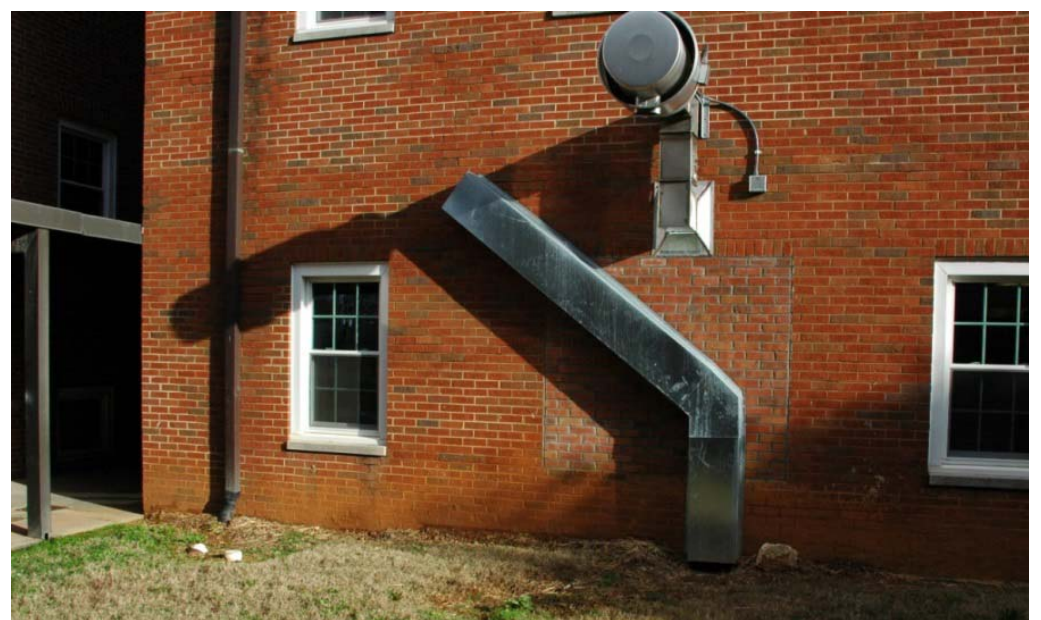

Figure 12. GHX loop headers attached to wall outside kitchen facility, Knoxville site

No "out of normal" GHX installation issues occurred for the Oklahoma City site.

Knoxville site GS-IHP installation cost estimate:

- GHX actual (per installer billing):

- GHX mid (without issues above):

- GHX low (mature market estimate):

- Trilogy unit:

- Indoor installation:

- Totals

high:

low:
$\$ 38,000$ ( $\$ 42 /$ bore $\mathrm{ft})$

$\$ 15,000(\sim 17 / \text { bore } \mathrm{ft})^{12}$

$\$ 9,600^{13}$ ( $\$ 10.70 /$ bore $\left.\mathrm{ft}\right)$

$\$ 9,800^{1415}$

$\$ 1,600^{16}$

$\$ 49,400$

$\$ 26,400$

\footnotetext{
${ }^{11}$ Personal communication, M. Davis (City Heat and AC) to Van Baxter, August 26, 2016.

${ }^{12}$ Compares to average GHX installation costs of $\$ 14.94 /$ bore $\mathrm{ft}$ in the South and $\$ 12.99 /$ bore $\mathrm{ft}$ in the Midwest based on a survey of GHSP systems in these regions; as reported by E. C. Battocletti and W. E. Glassley in "Measuring the Costs and Benefits of Nationwide Geothermal Heat Pump Deployment," prepared for the USDOE Geothermal Technologies Program, February 2013.

${ }^{13}$ Personal communication, D. Ellis (Comfortworks, Inc.) to Van Baxter, August 29, 2016. Estimated mature market GHX installation cost including drilling, u-tube pipe loop insertion, backfill/grouting of boreholes, trenching \& header pipe to building, and filling/flushing of GHX pipe loop.

${ }^{14}$ Personal communication, D. Ellis (Comfortworks, Inc.) to Van Baxter, August 29, 2016. Estimated mature market selling price for Trilogy unit including DHW tank, installation and commissioning.

${ }^{15}$ Compares to $\$ 5100$ for a typical (non-IHP and non-premium) WSHP unit as reported by E. C. Battocletti and W. E. Glassley in "Measuring the Costs and Benefits of Nationwide Geothermal Heat Pump Deployment," prepared for the USDOE Geothermal Technologies Program, February 2013.

${ }^{16}$ Includes removal of existing WH tank, connecting WSHP to GHX headers, water piping connections between WSHP and DHW tank, connection to existing building air ducts and water pipes.
} 
Knoxville site baseline RTU/HP + electric WH system install cost estimate:

- New RTU unit:

- Roof curb:

- Structural:

- Plans/Permits:

- Crane:

- Connection to existing ductwork:

- Total:
$\$ 4,100^{17}$

$\$ 1,500$

$\$ 1,700$

$\$ 2,000$

$\$ 1,000$

$\$ 1,000$

$\$ 11,300$

Except for the RTU, baseline installation cost estimates were based on costs given in the Gas Engine Heat Pump field demonstration report by Vineyard, at al. ${ }^{18}$ Before the IHP was installed heating and cooling for the kitchen facility at the site was supplied by a central system serving the entire building. Due to the heavy internal loads in the kitchen (due to refrigerator/freezer units, cooking equipment, dishwasher, etc.), the existing system had inadequate cooling capacity during workdays. So, for the baseline system used in this comparison it is assumed that a new RTU/HP dedicated to the kitchen area would be installed requiring some structural modifications to the roof to accommodate the weight of the unit along with new ductwork from the RTU to the existing kitchen ductwork. For the baseline water heating, it was assumed that the existing electric WH would be used so no install costs related to WH were included.

Oklahoma City site installation (new building) cost estimates: ${ }^{19}$

Total system estimate:

- GHX actual (per installer billing):

- Equipment (four WSHP units plus ERV):

- Indoor GHX loop and DHW tank connections:

- Totals:
$\$ 51,200(\sim \$ 10.2 /$ bore $\mathrm{ft})$

$\$ 39,100$

$\$ 6,500$

$\$ 141,200$

Subtotal estimate for one Trilogy IHP (assumes GHX loop with 1,250 bore ft total) :

- GHX:

- Equipment:

- Indoor GHX loop and DHW tank connections:

- Totals:
$\$ 12,800$ ( $\$ 10.2 /$ bore ft.)

$\$ 9,800$

$\$ 2,025$

$\$ 24,625$

\footnotetext{
${ }^{17}$ Price for 4-ton Goodman RTU from Ingram's website: http://ingramswaterandair.com/commercial-unitscommercial-package-heat-pump-c-45 170 173.html, accessed August 29, 2016

${ }^{18}$ Field Demonstration of Gas Heat Pump Rooftop Unit with Waste Heat Recovery for Water Heating. Ed Vineyard, Randall Wetherington, Mahabir Bhandari, and Jeff Munk. Oak Ridge National Laboratory, September 2105.

${ }^{19}$ Personal communication, D. Ellis (Comfortworks, Inc.) to Van Baxter, August 28, 2016. Total system equipment cost includes two Trilogy (IHP) WSHPs with 105 gal DHW tanks and two non-IHP WSHPs with thermostats and misc. materials along with one energy recovery ventilator (ERV) @\$6,800. Ductwork cost was $\$ 50,700$ for entire building; was assumed to be same for IHP and baseline installations.
} 
Oklahoma City baseline RTU/HP + electric WH system install cost estimate:

- New RTU unit:

$\$ 4,300^{20}$

- Roof curb:

$\$ 1,500$

- Structural:

$\$ 1,700$

- Plans/Permits:

$\$ 2,000$

- Crane:

$\$ 1,000$

- Connection to existing ductwork:

$\$ 1,000$

- New 105 gal electric WH

$\$ 1,900^{21}$

- Total:

$\$ 13,400$

\section{F. GS-IHP Control Verification, Performance-Related Issues, and Installation and Maintenance}

The Trilogy WSHP for the GS-IHP system includes an advanced, onboard control system that features VS compressor, indoor blower, GHX loop pump, and DHW loop pump capability. It also features recovery of normally rejected heat from the space cooling operation to provide domestic hot water for the building and year-round water heating capability at heat pump efficiency levels. These control strategies have successfully enabled both systems to function as designed and maintain space and hot water temperatures in the building with no complaints.

The only reported maintenance issue for the Knoxville site was failure of a main system control board at installation. CM provided a replacement board under warranty within a week and no further issues were encountered. There were two operation/control related issues we noted via observation of the performance data at the Oklahoma City site. In August and again in September the Trilogy WSHP unit went offline for just over 4 days ( 101 hours) when a power surge or other event caused the controls to shut it down. There was no space cooling available to the residential units and water heating was by the HW tank backup electric heating elements during both periods. However, no one at the shelter reported any problems to either ClimateMaster or the installing contractor (Comfort Works, Inc.). In both cases the Trilogy began normal operation again after the thermostat was adjusted. But whether the adjustment was by an automatic recovery feature in the controls (after a default timeout) or someone at the shelter manually adjusted the setting is not known.

The only routine maintenance required for the Trilogy unit is air filter change out twice per year at an estimated cost of $\$ 40$ each change $(\$ 80 / y)$.

${ }^{20}$ Price for 5-ton Goodman RTU from Ingram's website.

${ }^{21}$ Price quote from Home Depot in September 2016 for 105 gal electric WH $\sim 1500$; assumed $\$ 400$ for installation. 


\section{Annual Performance Results - Knoxville site}

Table 4 summarizes the overall GS-IHP performance monitoring results for the period from 2:00 pm on $8 / 18 / 2015$ through midnight of 8/18/2016 along with the assumptions/limitations of the comparison. Only SC and WH operation data are included in the table because no SH operation was required during the test year at the Knoxville site. The data set was missing only a three day period from March 24, 8am to March 27, 11am.

Table 4. Knoxville: GS-IHP summary performance comparison vs. baseline system

\begin{tabular}{|c|c|c|}
\hline & GS-IHP & $\begin{array}{c}\text { Baseline RTU + } \\
\text { electric WH }\end{array}$ \\
\hline \multicolumn{3}{|l|}{ Space Cooling (from SC and SC+WH modes) } \\
\hline Total Space Cooling Delivered (kWh) & 16729 & 16729 \\
\hline Sensible Cooling Delivered (kWh) & 14227 & 14227 \\
\hline Sensible heat ratio (SHR) & 0.85 & 0.85 \\
\hline SC Energy Use (kWh); \% savings vs. Baseline & $2165 ; 46.3 \%$ & 4032 \\
\hline Space Cooling COP & 7.73 & 4.15 \\
\hline \multicolumn{3}{|l|}{ Water Heating (from demand WH and SC+WH modes) } \\
\hline Total HW used (gal) & 19262 & 19262 \\
\hline Average working day HW use (gal/d) & 78.3 & 78.3 \\
\hline WH output from WSHP to WH tank (kWh) & 2730 & -- \\
\hline Water Heating Delivered to Building (kWh) & 2106 & 2106 \\
\hline Total WH Energy Use (kWh); \% savings vs. Baseline & $646 ; 72.4 \%$ & 2340 \\
\hline GS-IHP backup tank element energy use (kWh) & 1.5 & -- \\
\hline Water Heating COP & 3.26 & $0.90^{22}$ \\
\hline Water heating COP excluding tank/line losses & 4.23 & 1.00 \\
\hline Misc. energy consumption from controls, etc. (kWh) & 151 & 151 \\
\hline \multicolumn{3}{|l|}{ Overall } \\
\hline Energy Use (kWh) & 2962 & 6519 \\
\hline \% Energy savings & $54.6 \%$ & -- \\
\hline Carbon Equivalent Emissions $\left(\mathrm{CO}_{2}\right.$ metric tons) ${ }^{23}$ & 2.04 & 4.49 \\
\hline $\mathrm{CO}_{2}$ Emission Savings (metric tons) & 2.45 & -- \\
\hline
\end{tabular}

Assumptions

\footnotetext{
${ }^{22}$ Minimum energy factor (EF) rating for existing 50 gal electric storage WH manufactured before April 15, 2015 as rated per DOE test procedure https://www1.eere.energy.gov/buildings/appliance standards/product.aspx/productid/27.

${ }^{23}$ Estimated using a kWh-to- $\mathrm{CO}_{2}$ conversion factor of $6.89 \times 10^{-4}$ metric tons $/ \mathrm{kWh}$; taken from Energy Prices and Carbon Content (8/3/15 version) by Colin Weber.
} 
1) Baseline RTU sensible heat ratio (SHR) - a measure of latent cooling or dehumidification capacity - is the same as that estimated for Trilogy WSHP.

2) Baseline RTU is a $48,000 \mathrm{Btu} / \mathrm{h}$ (4 ton) rated cooling capacity unit (see Table 1 for other ratings)

3) Baseline RTU fan power is $365 \mathrm{~W} / 1000 \mathrm{cfm}$ (taken from the current AHRI 210/240 ratings procedure ${ }^{24}$ )

4) Baseline RTU misc. energy use is the same as that measured for the Trilogy WSHP

5) Energy use for the combined $\mathrm{SC}+\mathrm{WH}$ mode is divided between $\mathrm{SC}$ and $\mathrm{WH}$ proportional to the output capacities. Basically the COP for WH and SC in the combined mode is assumed to be the same. This has the effect of lowering the SC efficiency a bit (due to the higher condensing pressures required for the $\mathrm{SC}+\mathrm{WH}$ mode) and raising the $\mathrm{WH}$ efficiency relative to the SC-only and dedicated WH mode efficiencies.

6) The Trilogy sensible cooling and subsequent SHR are calculated based on the cfm provided by the Trilogy unit, an assumption of $0.075 \mathrm{lbm} / \mathrm{ft}^{3}$ air density, and measured return and supply air temperatures.

7) The baseline system is assumed to use the existing electric $\mathrm{WH}$ at the site; rated energy factor (EF) is assumed to be 0.9 (minimum EF required for electric WHs manufactured before April 1, 2015).

Note that the SC mode energy savings are likely somewhat conservative. This is due to the assumption that both the IHP and the Baseline RTU maintained similar comfort (sensible and latent SC loads) as discussed in section IV.C above. Since the RTU does not have a VS blower like the IHP it would likely have to consume more energy to meet the same latent SC loads.

Figure 13 provides a graphical comparison of the monthly average overall SC COPs for the GS-IHP and Baseline RTU/heat pump. The GS-IHP SC COPs in the plot include SC delivered in both SC-only and $\mathrm{SC}+\mathrm{WH}$ modes.

${ }^{24}$ Air-conditioning, Heating, and Refrigeration Institute, ANSI/AHRI Standard 210/240-2008 with Addenda 1 and 2, "Performance Rating of Unitary Air-Conditioning \& Unitary Heat Pump Equipment," March 2012. 


\section{Average monthly space cooling COPs}

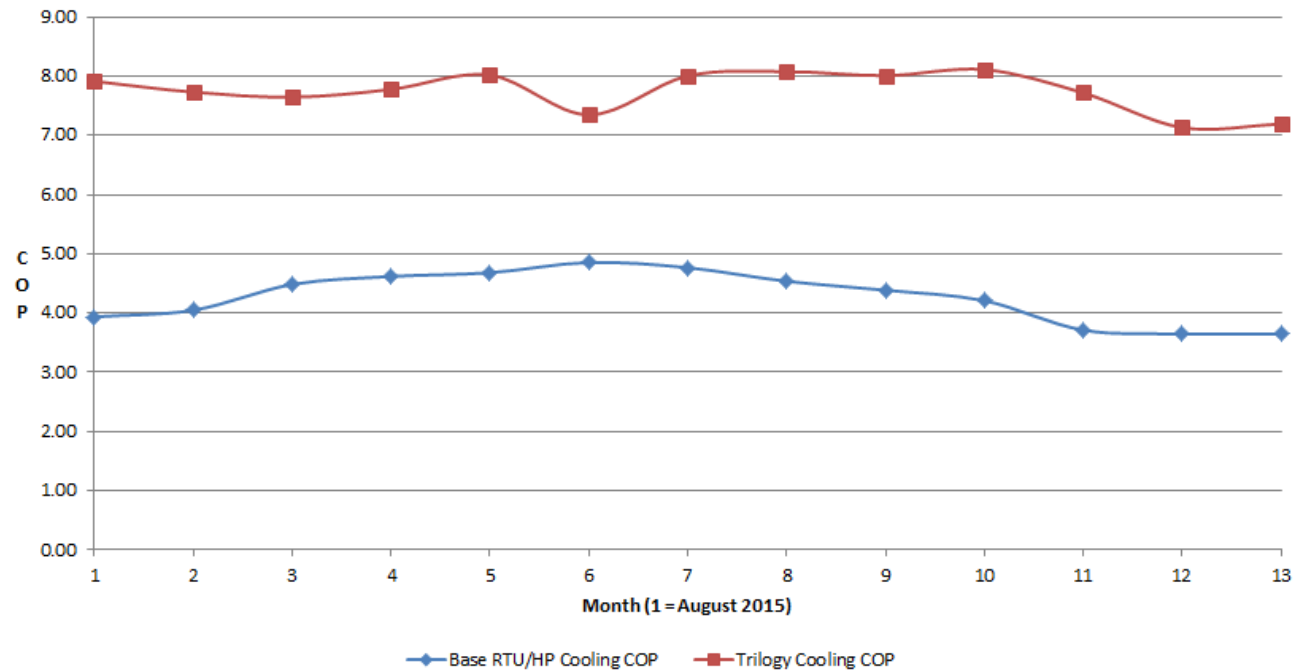

Figure 13. Knoxville: Trilogy WSHP vs. Baseline RTU/heat pump SC monthly average COPs

Table 5 provides a summary of the average COPs for the GS-IHP system for each of its active operating modes over the test year. Note that the overall SC mode COP for the GS-IHP system in Table 5 (8.0) does not include the impact of the SC energy delivered during the combined SC+WH mode. The GS-IHP SC COP reported in Table 4 (7.73) does include that impact, accounting for the slight difference in the COP values. But most of the SC load during the year ( 92.5\%) was delivered during SC-only mode (most efficient for SC). Table 5 also includes the estimated RTU SC COP for comparison. Note that the two WH mode COPs in Table $5(\mathrm{SC}+\mathrm{WH}$ and demand $\mathrm{WH})$ are based on the $\mathrm{WH}$ delivered at the exit of the Trilogy WSHP to the WH tank and connecting lines. Thus they are comparable to the WH COP excluding tank/line losses in Table 4. Most of the WH load was delivered during SC+WC mode ( 67\%), the most efficient for WH.

Table 5. Knoxville: Approximate overall average GS-IHP COPs by operation mode

\begin{tabular}{|c|c|c|c|c|}
\hline & $\begin{array}{c}\text { GS-IHP SC- } \\
\text { only mode }\end{array}$ & $\begin{array}{c}\text { GS-IHP SC+WH } \\
\text { mode }^{\mathrm{a}}\end{array}$ & $\begin{array}{c}\text { GS-IHP demand } \\
\text { WH mode }\end{array}$ & $\begin{array}{c}\text { Baseline RTU } \\
\text { SC-only COP }\end{array}$ \\
\hline Total period & 8.0 & 5.6 & 3.2 & 4.14 \\
\hline
\end{tabular}

${ }^{a}$ Based on WH delivered from WSHP to WH tank (excludes tank \& connecting line losses)

The primary reason the GS-IHP performed so much better than the baseline is that the entering water temperature (EWT) to the WSHP from the GHX loop was generally significantly more favorable than the outdoor air temperature (OAT) during hours when space cooling or demand WH operation was required at the site. Figure 14 compares the hourly OAT and EWT of the Trilogy in both modes. In the hottest parts of the summer the EWT was consistently cooler (by $>20^{\circ} \mathrm{F}$ ) than the OD air which minimized the condensing pressure leading to improved SC mode efficiency. In winter months the EWT was much 
warmer than the OD air benefitting the GS-IHP WH mode efficiency. Figure 14 also shows that the EWT at the end of the monitoring period was essentially the same as in August 2015 when the unit began operating. This indicates that, despite the heavily SC-load dominated operation all year and addition of the antifreeze solution in January, there was no discernable warming of the ground surrounding the GHX bores during this first year of operation. It is possible that the GHX loop could have been somewhat shorter, reducing system cost though sacrificing some energy saving potential due to reduced efficiency.

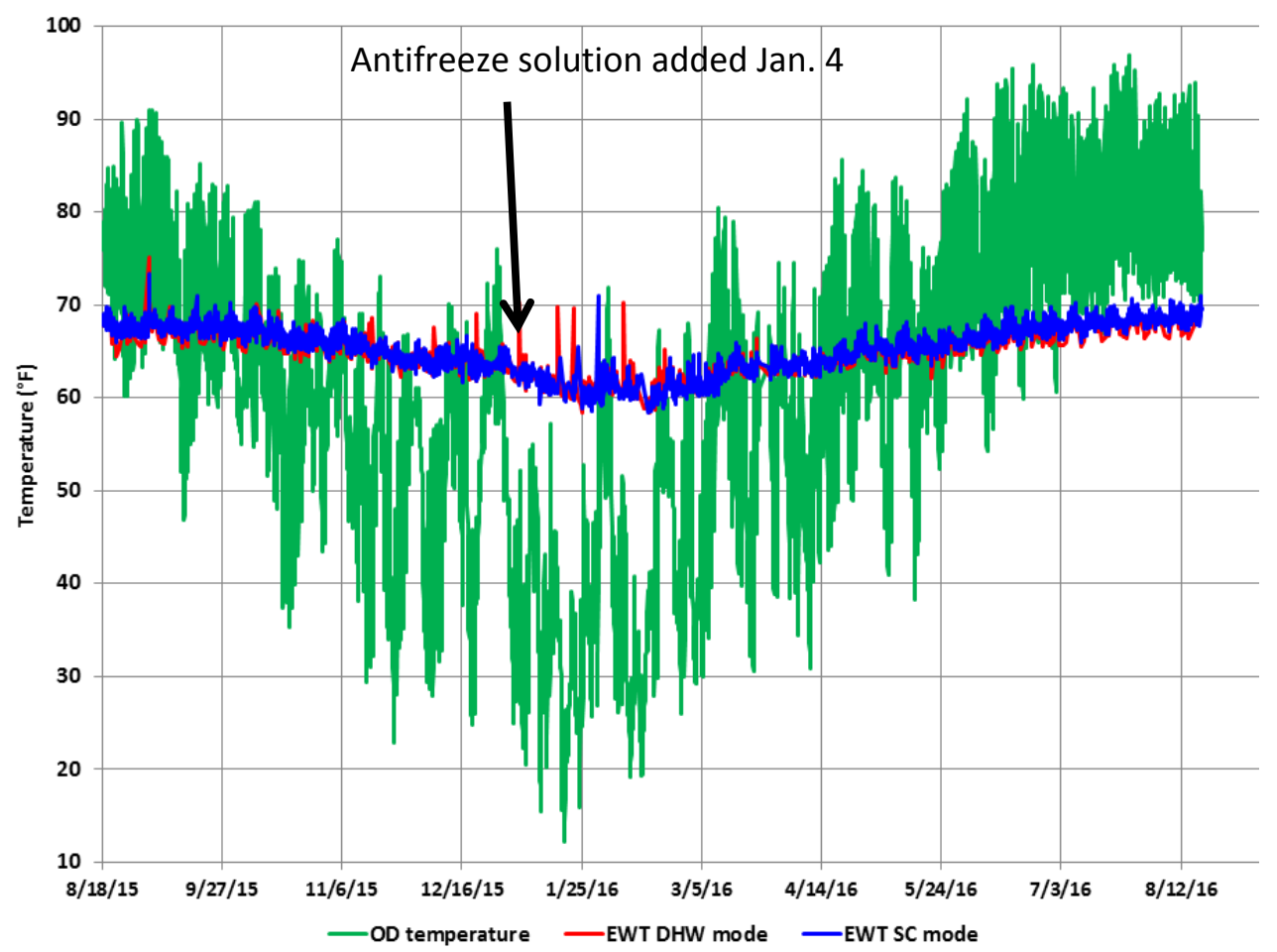

Figure 14. Knoxville: Trilogy WSHP EWT vs. OAT

Also, as a side note, the kitchen staff kept the SC set point fairly low as evidenced by the space temperature history during the test period, shown in Figure 15, below. During the occupied periods (week days) the air temperature in the kitchen ranged as low as $\sim 64^{\circ} \mathrm{F}$. 


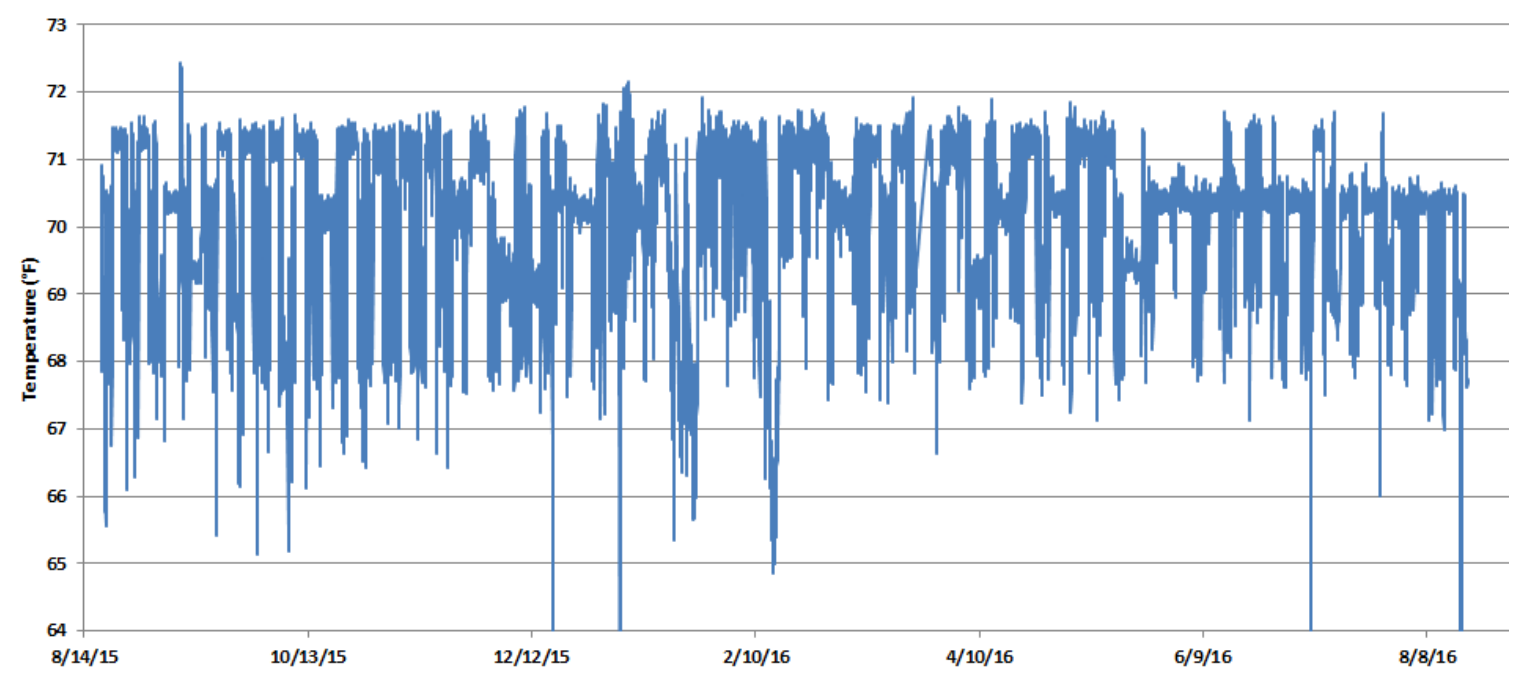

Figure 15. Knoxville: Kitchen space temperature measured at thermostat during test year

In addition to the energy savings, the GS-IHP system achieved significant reductions in hourly average kW demand at the Knoxville site. Monthly peak hour kW demand is shown in Table 6 for the GS-IHP and Baseline systems. The maximum average hourly demand each month for the GS-IHP ranged from $54 \%$ to $78 \%$ lower than that of the baseline system.

Table 6. Knoxville: Peak hourly kW demand by month, GS-IHP vs. Baseline

\begin{tabular}{|c|c|c||c|c|}
\hline Month & $\begin{array}{c}\text { GS-IHP } \\
\text { demand, } \\
\text { kW }\end{array}$ & Date & $\begin{array}{c}\text { Baseline } \\
\text { demand, kW }\end{array}$ & \\
\hline Aug. 18-31, 2015 & 1.705 & -- & 4.545 & -- \\
\hline September 2015 & 2.923 & $9 / 2 / 15$, noon-1pm & 4.349 & $9 / 2 / 15,1-2 \mathrm{pm}$ \\
\hline October 2015 & 1.642 & -- & 5.290 & -- \\
\hline November 2015 & 1.888 & $11 / 6 / 15$, noon-1pm & 5.444 & $11 / 10 / 15,1-2 \mathrm{pm}$ \\
\hline December 2015 & 1.603 & -- & 7.110 & -- \\
\hline January 2016 & 1.593 & -- & 5.508 & -- \\
\hline February 2016 & 1.538 & -- & 5.407 & -- \\
\hline March 2016 & 1.664 & -- & 5.969 & -- \\
\hline April 2016 & 1.510 & -- & 5.647 & $5 / 20 / 16,2-3 p m$ \\
\hline May 2016 & 1.778 & -- & 5.676 & -- \\
\hline June 2016 & 2.301 & $6 / 14 / 16$, noon-1pm & 10.425 & $6 / 16 / 16$, noon-1pm \\
\hline July 2016 & 1.682 & -- & 5.557 & -- \\
\hline Aug. 1-18, 2016 & 1.331 & -- & 5.280 & -- \\
\hline Total period & 2.923 & $9 / 2 / 15$, noon-1pm & 10.425 & $6 / 16 / 16$, noon-1pm \\
\hline
\end{tabular}

It can be noted, however, that perhaps the most significant factor influencing the IHP system peak demand at this specific location was the kitchen staff behavior. Figure 16 illustrates the hourly IHP 
system and tank element power and baseline RTU/HP system power along with outdoor temperature, hot water tank temperature (at top element location), the thermostat cooling set point temperature, and the hot water consumption for the week beginning August 30, 2015. [Note: the IHP and tank element power values are divided by 100 in order to make all the parameters fit on the chart.] Both the IHP and baseline system September peak demands occurred on Wednesday of that week. The IHP peak demand (purple line) is not coincident with the outdoor temperature (orange line). Rather, it coincides with the point where the kitchen staff lowered the thermostat set temperature (light blue line) from 68 ${ }^{\circ} \mathrm{F}$ to $66^{\circ} \mathrm{F}$ causing the system to ramp up to almost maximum compressor speed (light purple line) for about a full hour to meet the sudden increase in space cooling demand. On the day before, with similar OD temperatures and slightly lower peak HW demand but no sudden set point reduction, the IHP peak was only about half ( $1.52 \mathrm{~kW}$ vs. $2.92 \mathrm{~kW}$ ). In contrast the baseline system, which does not have variable capacity capability to improve efficiency, peak demand (red line) was estimated to be only about $0.2 \mathrm{~kW}$ lower ( $4.11 \mathrm{~kW}$ vs. $4.32 \mathrm{~kW}$ ). Similar thermostat adjustments were largely responsible for the IHP system peaks in November and June as well. Had these occupant thermostat changes not occurred it is estimated that the IHP maximum monthly peak demands would have been in the 1.5 to $1.8 \mathrm{~kW}$ range every month. The average hourly compressor speed absent thermostat adjustments generally ranged from $\sim 50 \%$ to $\sim 70 \%$ of the maximum speed at this site.

\section{Hourly averages (temperatures, ${ }^{\circ} \mathrm{F}$ ) or totals (gallons, $\mathrm{Wh} / 100$ )}

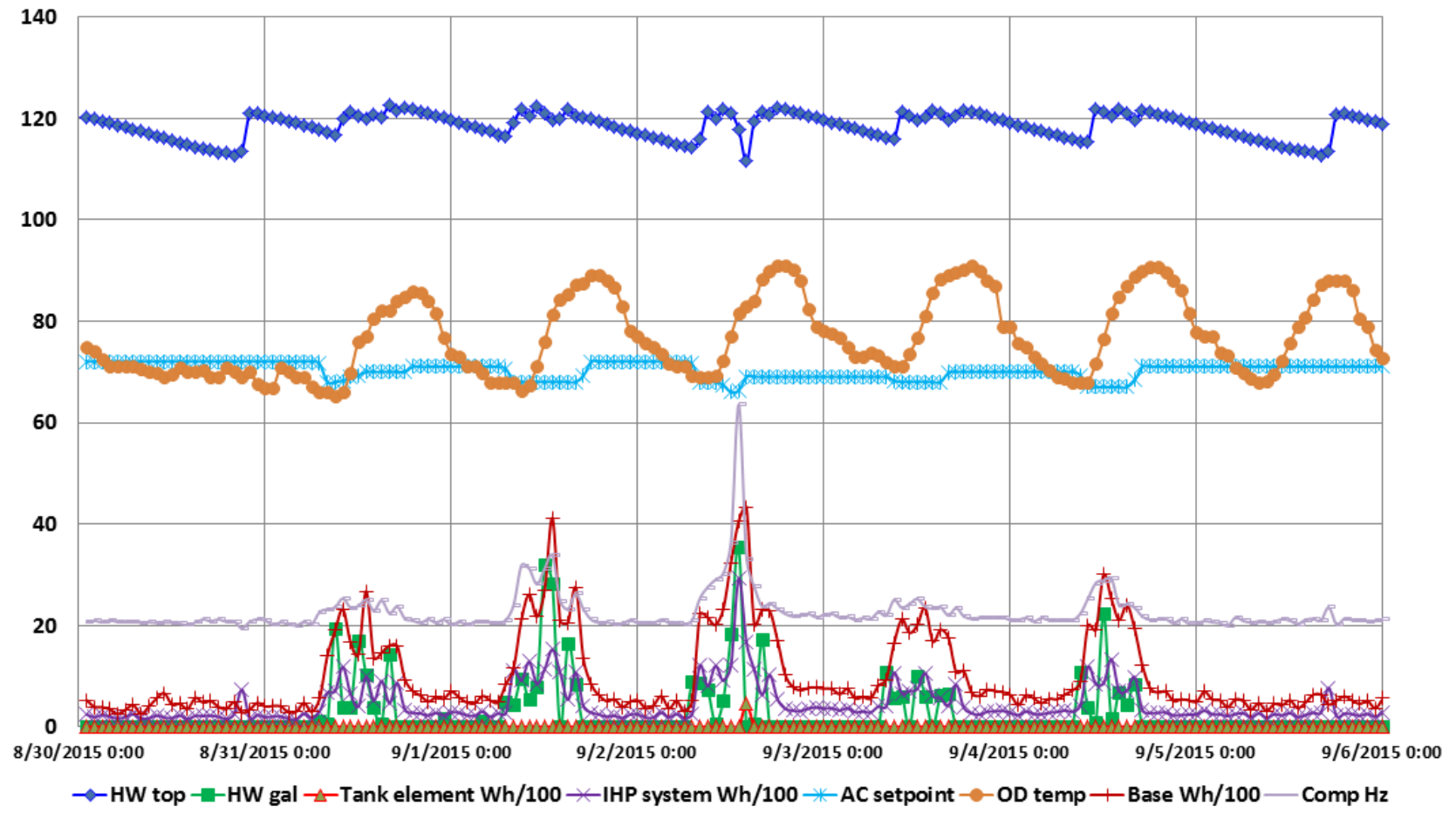

Figure 16. Knoxville: Maximum IHP hourly peak demand week 
Energy cost savings for the Knoxville site were computed based on the energy and demand savings from Tables 4 and 6, and the commercial rate data from the Knoxville Utilities Board (KUB). ${ }^{25}$ For the summer months of June, July, August and September, KUB charges $\$ 0.12171 / \mathrm{kWh}$ and $\$ 13.92 / \mathrm{kW}$. For all other months the rates are $\$ 0.12130 / \mathrm{kWh}$ and $\$ 13.13 / \mathrm{kW}$. Costs and savings for the GS-IHP vs. the Baseline are given in Table 7. Total energy cost savings were $\sim 64 \%$, about $65 \%$ of which are due to the lower demand charges.

Table 7. Knoxville: GS-IHP HVAC/WH energy cost savings (8/18/15 - 8/18/16)

\begin{tabular}{|l|c|c|}
\hline & $\begin{array}{c}\text { Baseline RTU/heat } \\
\text { pump and electric } \\
\text { WH }\end{array}$ & GS-IHP \\
\hline Electricity consumption & $\$ 792$ & $\$ 360$ \\
\hline Electricity demand & $\$ 1,052$ & $\$ 312$ \\
\hline Total costs & $\$ 1844$ & $\$ 672$ \\
\hline Energy cost savings vs. Baseline & -- & $\$ 1172$ \\
\hline \%cost savings vs. Baseline & -- & $63.6 \%$ \\
\hline
\end{tabular}

\section{Oklahoma City Performance Results}

As noted above (see Section IV.B), the Oklahoma City DAQ system became functional for SH and SC mode data collection on January 31 but not for the WH modes until late April. Therefore monitored data are not available to support a full year's performance summary as was the case for the Knoxville site. So this section provides a summary of the IHP system performance vs. the baseline for each individual mode. Note that there are a number of gaps in the data as detailed below.

Data availability January through August 2016:

- January --- data collection began Jan. 31 at 8am; space heating data only

- February --- space heating data available all month

- March --- space heating data available all month

- April --- space heating and space cooling data available through April 28, 3pm

- May --- no data up through May 19,1pm; all data available May 19 - May 31

- June --- data missing from June 10,6pm through June 15, 6pm; all data available remainder of month

- July --- all data available

\footnotetext{
${ }^{25}$ Knoxville Utilities Board, General Power Rate - Schedule GSA, July 2016. http://www.kub.org/wps/wcm/connect/3bfe2f80424c71338027b1d8d4cab33c/GSAJuly.pdf?MOD=AJPERES\&CAC HEID=3bfe2f80424c71338027b1d8d4cab33c
} 
- August --- all data available except for August 12-16 outage due to control issue (described in section IV.F)

- September --- data through September 19, 1pm except for September 3-7 outage due to control issue

The assumptions listed under Table 4 for the Knoxville site data analyses (reiterated below with two differences as noted) also apply to the Oklahoma City site data analyses.

Assumptions

1) Baseline RTU SHR is the same as that estimated for Trilogy WSHP.

2) Baseline RTU is a $60,000 \mathrm{Btu} / \mathrm{h}$ (5 ton) rated cooling capacity unit $(48,000 \mathrm{Btu} / \mathrm{h}$ or 4 ton for the Knoxville site due to lower design load)

3) Baseline RTU fan power is $365 \mathrm{~W} / 1000 \mathrm{cfm}$ (taken from the current AHRI 210/240 ratings procedure)

4) Baseline RTU misc. energy use is the same as that measured for the Trilogy WSHP

5) Energy use for the combined $\mathrm{SC}+\mathrm{WH}$ mode is divided between $\mathrm{SC}$ and $\mathrm{WH}$ proportional to the output capacities. Basically the COP for WH and SC in the combined mode is assumed to be the same. This has the effect of lowering the SC efficiency a bit (due to the higher condensing pressures required for the $\mathrm{SC}+\mathrm{WH}$ mode) and raising the $\mathrm{WH}$ efficiency relative to the SC-only and dedicated WH mode efficiencies.

6) The Trilogy sensible cooling and subsequent SHR are calculated based on the cfm provided by the Trilogy unit, an assumption of $0.075 \mathrm{lbm} / \mathrm{ft}^{3}$ air density, and measured return and supply air temperatures.

7) The baseline system is assumed to require a new electric $\mathrm{WH}$; rated energy factor (EF) of 0.94 (minimum EF required for electric WHs manufactured after April 1, 2015). For Knoxville we assumed the original electric WH (installed prior to April 2015) was used; $\mathrm{EF}=0.9$.

Tables 8-10 summarize the Oklahoma City GS-IHP performance for SH, SC, and WH operation, respectively.

As shown in Table 8, the IHP system demonstrated an overall SH COP of almost 5.0 and energy and cost savings of $~ 52 \%$ over the 61.7 days for which data were available. Energy cost savings for the Oklahoma City were computed using the standard residential service rates from the Oklahoma Gas and Electric Company (OGE).${ }^{26}$ OGE charges a standard rate of $\$ 0.0573 / \mathrm{kWh}$ year-round with a slightly higher rate $(\$ 0.068)$ in June-September for consumption in excess of $1400 \mathrm{kWh} / \mathrm{month}$ and a lower rate $(\$ 0.0173)$ in November-May for consumption in excess of $600 \mathrm{kWh} / \mathrm{month}$. For purposes of our analyses we assumed the standard rate applied all year. Total electric cost savings for the monitored unit were $\sim \$ 43$. Assuming the average $\mathrm{SH}$ daily load and efficiency for the entire heating season would be the same as

\footnotetext{
${ }^{26}$ Oklahoma Gas and Electric Company, Standard Pricing Schedule: R-1 Residential Service, August 2012. https://oge.com/wps/wcm/connect/de21b39f-2d52-402f-82e6-a6826999d724/3.00+R1.pdf?MOD=AJPERES\&CACHEID=de21b39f-2d52-402f-82e6-a6826999d724
} 
that for the monitored period, total SH energy and cost savings are estimated to be $\sim 2060 \mathrm{kWh}$ and $\$ 118$. Since there are two IHP units in the building the SH cost savings would double to $\sim 236$.

Table 8. Oklahoma City: SH performance comparison, IHP vs. Baseline RTU/HP

\begin{tabular}{|c|c|c|c|c|c|c|c|c|}
\hline Month & $\begin{array}{c}\text { IHP } \\
\text { COP }\end{array}$ & $\begin{array}{c}\text { SH } \\
\text { Delivered } \\
\mathrm{kWh}\end{array}$ & $\begin{array}{c}\text { IHP SH } \\
\text { Energy } \\
\text { use } \\
\mathrm{kWh}\end{array}$ & $\begin{array}{c}\text { Baseline } \\
\text { RTU } \\
\text { Energy } \\
\text { use } \\
\mathrm{kWh}\end{array}$ & $\begin{array}{c}\text { IHP } \\
\text { Energy } \\
\text { Savings } \\
\%\end{array}$ & $\begin{array}{c}\text { IHP SH } \\
\text { Energy } \\
\text { cost } \\
\$\end{array}$ & $\begin{array}{c}\text { Baseline } \\
\text { RTU } \\
\text { Energy } \\
\text { cost } \\
\$\end{array}$ & $\begin{array}{c}\text { IHP } \\
\text { Energy } \\
\text { cost } \\
\text { Savings } \\
\%\end{array}$ \\
\hline Jan 31 & 4.86 & 26.93 & 5.54 & 10.37 & $46.6 \%$ & $\$ 0.32$ & $\$ 0.59$ & $46.6 \%$ \\
\hline Feb & 4.85 & 2101.82 & 433.43 & 915.40 & $52.7 \%$ & $\$ 24.84$ & $\$ 52.45$ & $52.7 \%$ \\
\hline Mar & 5.04 & 1062.94 & 211.02 & 426.51 & $50.5 \%$ & $\$ 12.09$ & $\$ 24.44$ & $50.5 \%$ \\
\hline Apr 1-28 & 5.27 & 263.43 & 49.94 & 99.99 & $50.0 \%$ & $\$ 2.86$ & $\$ 5.73$ & $50.0 \%$ \\
\hline Total & 4.94 & 3455.12 & 699.94 & 1452.57 & $51.8 \%$ & $\$ 40.11$ & $\$ 83.21$ & $51.8 \%$ \\
\hline
\end{tabular}

For SC operation data was available for 117.6 days, over which the IHP demonstrated a COP of 6.9 with almost 50\% energy and electric cost savings compared to the estimated performance of the baseline RTU (Table 9). The delivered SC energy to the building is a combination of the SC delivered in two modes; SC only and SC+WH; $87 \%$ of the total SC load was delivered in SC-only mode operation. Total electricity cost savings for the monitored unit were $\sim \$ 105$. It can be noted that OGE also offers residential customers a time-of-use (TOU) rate option for June-October; from 2-7pm the electricity use rate is $\$ 0.14 / \mathrm{kWh}$ and for all other hours it is $\$ 0.027 / \mathrm{kWh}$. With the TOU rate, both the IHP SC energy $\$$ and $\%$ cost savings for the period would drop slightly to $\sim \$ 100$ and $\sim 50 \%$, respectively. Note that the measured SC savings at this site are also likely to be somewhat conservative due to the assumption that the Baseline RTU could maintain similar comfort levels as that provided by the IHP (see discussion in section IV.C).

Assuming the average SC daily load and efficiency for the entire cooling season would be the same as that for the monitored period, total SC energy and cost savings are estimated to be $\sim 2760 \mathrm{kWh}$ and $\sim$ \$158. Since there are two IHP units in the building the SH cost savings would double to $\sim \$ 316$. 
Table 9. Oklahoma City: SC cooling performance comparison, IHP vs. Baseline RTU/HP

\begin{tabular}{|c|c|c|c|c|c|c|c|c|}
\hline Month & $\begin{array}{l}\text { IHP } \\
\text { COP }\end{array}$ & $\begin{array}{c}\text { Total SC } \\
\text { Delivered } \\
\text { kWh }\end{array}$ & \begin{tabular}{|c} 
Total IHP \\
SC \\
Energy \\
use \\
kWh
\end{tabular} & $\begin{array}{c}\text { Baseline } \\
\text { RTU } \\
\text { Energy } \\
\text { use } \\
\text { kWh }\end{array}$ & $\begin{array}{c}\text { IHP } \\
\text { Energy } \\
\text { Savings } \\
\%\end{array}$ & $\begin{array}{c}\text { IHP SC } \\
\text { Energy } \\
\text { cost } \\
\$\end{array}$ & $\begin{array}{c}\text { Baseline } \\
\text { RTU } \\
\text { Energy } \\
\text { cost } \\
\$\end{array}$ & $\begin{array}{c}\text { IHP } \\
\text { Energy } \\
\text { cost } \\
\text { Savings } \\
\%\end{array}$ \\
\hline Apr 1-28 & 7.17 & 98.48 & 13.73 & 25.92 & $47.0 \%$ & $\$ 0.79$ & $\$ 1.49$ & $47.0 \%$ \\
\hline May $19-31$ & 8.39 & 950.14 & 113.19 & 247.30 & $54.2 \%$ & $\$ 6.49$ & $\$ 14.17$ & $54.2 \%$ \\
\hline June $^{a}$ & 7.08 & 3697.49 & 522.51 & 1045.08 & $50.0 \%$ & $\$ 29.94$ & $\$ 59.88$ & $50.0 \%$ \\
\hline July & 6.60 & 4594.56 & 695.99 & 1356.30 & $48.7 \%$ & $\$ 39.88$ & $\$ 77.72$ & $48.7 \%$ \\
\hline Aug $^{b}$ & 6.80 & 3229.54 & 475.22 & 939.58 & $49.4 \%$ & $\$ 27.23$ & $\$ 53.84$ & $49.4 \%$ \\
\hline $\mathrm{Sept}^{\mathrm{c}}$ & 8.05 & 366.95 & 45.56 & 98.87 & $53.9 \%$ & $\$ 2.61$ & $\$ 5.67$ & $53.9 \%$ \\
\hline Total & 6.93 & 12937.16 & 1866.19 & 3713.05 & $49.7 \%$ & $\$ 104.32$ & $\$ 212.76$ & $49.7 \%$ \\
\hline
\end{tabular}

Estimated WH performance at Oklahoma City is given in Table 10 (note that performance at this site is estimated assuming that the ratio of WH delivered to the building is the same as measured at the Knoxville site as discussed earlier in Section IV.C). Operation data was available for 109.6 days total. For that period the IHP's estimated WH mode COP was $\sim 4.449$ with $\sim 79 \%$ energy and electricity cost savings compared to the baseline electric $\mathrm{WH}$, while delivering almost $189 \mathrm{gal} / \mathrm{d}$ of hot water to the residential units in the building ( $\sim 19$ gallons/day/unit). The delivered WH energy to the building is a combination of the $\mathrm{WH}$ delivered to the building in two modes: dedicated $\mathrm{WH}$ and $\mathrm{SC}+\mathrm{WH}$ with over $80 \%$ coming during the $\mathrm{SC}+\mathrm{WH}$ operating mode. Total electricity cost savings for the monitored unit were $\sim 131$. With the TOU rate assumption, IHP WH energy $\$$ and $\%$ cost savings for the period would drop slightly to $\sim 125$ and $\sim 75 \%$, respectively. Modification of the Trilogy controls, e.g., to delay WH operation until after peak periods, limit maximum compressor and fan speeds during peak periods, etc., could yield higher energy cost savings with the TOU rate.

Assuming the average WH daily load and efficiency for the entire year would be the same as that for the monitored period, total WH energy and cost savings are estimated to be $\sim 12460 \mathrm{kWh}$ and $\sim \$ 714$. Since there are two IHP units in the building the SH cost savings would double to $\sim$ 1428. 
Table 10. Oklahoma City: WH performance comparison, IHP vs. Baseline RTU/HP

\begin{tabular}{|c|c|c|c|c|c|c|c|}
\hline Month & $\begin{array}{c}\text { Daily hot } \\
\text { water } \\
\text { use, } \\
\text { gal/d }\end{array}$ & $\begin{array}{l}\text { IHP } \\
\text { COP }\end{array}$ & $\begin{array}{l}\text { Total WH } \\
\text { Delivered to } \\
\text { bldg. } \\
\text { kWh }\end{array}$ & $\begin{array}{c}\text { Total IHP WH } \\
\text { Energy use } \\
\text { kWh } \\
\text { (tank element } \\
\text { kWh) } \\
\end{array}$ & $\begin{array}{c}\text { Baseline } \\
\text { WH } \\
\text { Energy use } \\
\text { kWh }\end{array}$ & $\begin{array}{c}\text { IHP WH } \\
\text { Energy cost } \\
\$\end{array}$ & $\begin{array}{c}\text { Baseline WH } \\
\text { Energy cost } \\
\$\end{array}$ \\
\hline $\begin{array}{c}\text { May 19- } \\
31 \\
\end{array}$ & 161 & 4.12 & 127.17 & $\begin{array}{l}30.84 \\
(0.21) \\
\end{array}$ & 133.19 & $\$ 1.77$ & $\$ 7.63$ \\
\hline June $^{a}$ & 167 & 4.27 & 286.64 & $\begin{array}{l}67.09 \\
(3.68)\end{array}$ & 302.64 & $\$ 3.84$ & $\$ 17.34$ \\
\hline July & 182 & 4.72 & 1008.41 & $\begin{array}{l}213.81 \\
(4.99)\end{array}$ & 1062.5 & $\$ 12.25$ & $\$ 60.88$ \\
\hline Aug $^{b}$ & 181 & 4.45 & 808.35 & $\begin{array}{l}181.59 \\
(9.77)\end{array}$ & 853.48 & $\$ 10.41$ & $\$ 48.909$ \\
\hline $\operatorname{Sept}^{\mathrm{c}}$ & 280 & 4.12 & 530.84 & $\begin{array}{l}128.94 \\
(0.68)\end{array}$ & 564.25 & $\$ 7.39$ & $\$ 32.33$ \\
\hline $\begin{array}{c}\text { Total } \\
\text { \% } \\
\text { savings }\end{array}$ & 189 & 4.44 & 2761.42 & $\begin{array}{l}622.28 \\
(19.11) \\
78.7 \%\end{array}$ & 2916.05 & $\$ 35.66$ & $\begin{array}{c}\$ 167.09 \\
78.7 \%\end{array}$ \\
\hline
\end{tabular}

agap in data from June 10-15.

bap in data from August 12-16.

'gap in data from September 3-7.

Table 11 provides a summary of the average COPs for the Oklahoma City GS-IHP system for each of its active operating modes over the test year. Note that the SC COP for the GS-IHP system in Table 9 above (6.93) is very close to both the SC-only and SC+WH mode COPs (7.0) as seen in Table 11 . About $88 \%$ of the total SC load was delivered in the SC-mode. Note also that the two WH mode COPs in Table 11 ( $\mathrm{SC}+\mathrm{WH}$ and demand $\mathrm{WH}$ ) are based on the $\mathrm{WH}$ delivered at the exit of the Trilogy WSHP to the WH tank and connecting lines. The WH loads in Table 10 are "as delivered to the WH tank" and the COPs, thus, lower than those in Table 11 since they include the tank and connecting line losses. Table 11 also includes estimated RTU SC and SH COPs at the Oklahoma City site for comparison.

Table 11. Oklahoma City: Approximate overall average GS-IHP COPs by operation mode

\begin{tabular}{|c|c|c|c|c|c|c|}
\hline & $\begin{array}{c}\text { GS-IHP SH- } \\
\text { mode }\end{array}$ & $\begin{array}{c}\text { GS-IHP SC- } \\
\text { only mode }\end{array}$ & $\begin{array}{c}\text { GS-IHP } \\
\text { SC+WH } \\
\text { mode }^{\mathrm{a}}\end{array}$ & $\begin{array}{c}\text { GS-IHP } \\
\text { demand WH } \\
\text { mode }^{\mathrm{a}}\end{array}$ & $\begin{array}{c}\text { Baseline } \\
\text { RTU SC-only } \\
\text { COP }\end{array}$ & $\begin{array}{c}\text { Baseline } \\
\text { RTU SH } \\
\text { COP }\end{array}$ \\
\hline Total period & 4.9 & 7.0 & 7.0 & 4.8 & 3.5 & 2.4 \\
\hline
\end{tabular}

${ }^{\mathrm{a}}$ Based on WH delivered from WSHP to WH tank (excludes tank \& connecting line losses) 
As for the Knoxville site, the entering water temperature (EWT) to the WSHP from the GHX loop was generally significantly more favorable than the outdoor air temperature (OAT) during hours when SH, SC, or WH operation was required. Figure 17 compares the hourly OAT and EWT of the Trilogy for these operating modes (combined SC+WH mode does not use the GHX). In the hottest parts of the summer the EWT was consistently cooler (by $\sim 5-25^{\circ} \mathrm{F}$ ) than the OD air which minimized the condensing pressure leading to improved SC mode efficiency. In winter months the EWT was warmer than the OD air on average benefitting the GS-IHP SH and WH mode efficiency.

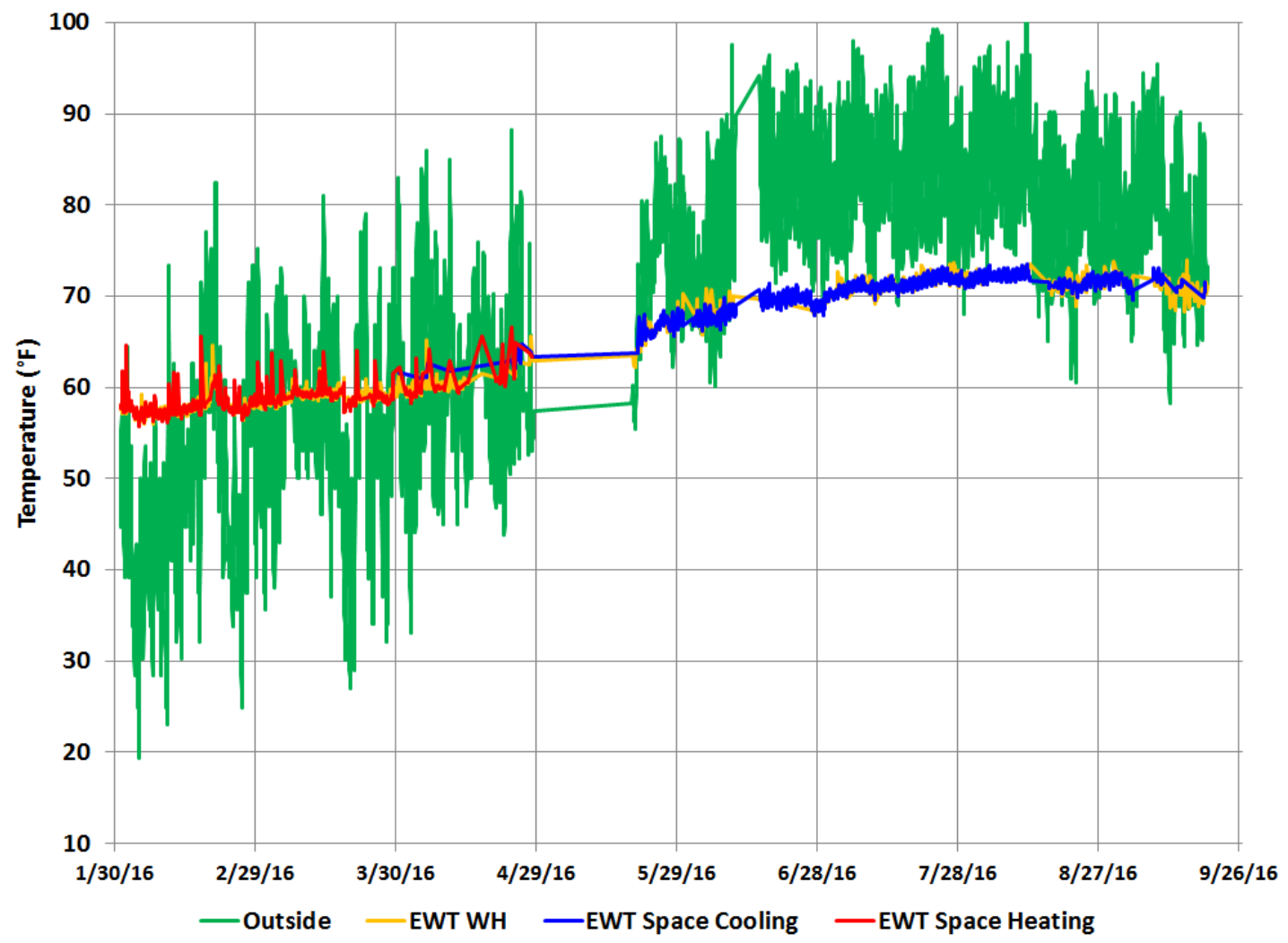

Figure 17. Oklahoma City: Trilogy WSHP EWT vs. OAT

Monthly hourly average peak kW demand at the Oklahoma City site is shown in Table 12 for the GS-IHP and Baseline systems.

Table 12. Oklahoma City: Peak hourly kW demand by month, GS-IHP vs. Baseline

\begin{tabular}{|c|c|c|c|c|}
\hline Month & $\begin{array}{c}\text { GS-IHP } \\
\text { demand, } \\
\text { kW }\end{array}$ & Date & $\begin{array}{c}\text { Baseline } \\
\text { demand, } \\
\text { kW }\end{array}$ & Date \\
\hline January & 0.937 & -- & 2.869 & -- \\
\hline February & 3.388 & $2 / 27 / 16,4-5 \mathrm{am}$ & 10.283 & $2 / 26 / 16,4-5 \mathrm{am}$ \\
\hline
\end{tabular}




\begin{tabular}{|c|c|c||c|c|}
\hline Month & $\begin{array}{c}\text { GS-IHP } \\
\text { demand, } \\
\mathrm{kW}\end{array}$ & Date & $\begin{array}{c}\text { Baseline } \\
\text { demand, } \\
\mathrm{kW}\end{array}$ & Date \\
\hline March & 3.139 & $3 / 19 / 16,1-2 \mathrm{am}$ & 10.574 & $3 / 19 / 16,2-3 \mathrm{am}$ \\
\hline April & 4.437 & $4 / 13 / 16,6-7 \mathrm{pm}$ & 7.302 & $4 / 2 / 16,4-5 \mathrm{am}$ \\
\hline May & 2.289 & $5 / 25 / 16,6-7 \mathrm{pm}$ & 6.605 & $5 / 28 / 16,4-5 \mathrm{pm}$ \\
\hline June & 6.367 & $6 / 14 / 16,5-6 \mathrm{pm}$ & 7.960 & $6 / 14 / 16,5-6 \mathrm{pm}$ \\
\hline July & 5.671 & $7 / 27 / 16,5-6 \mathrm{pm}$ & 9.869 & $7 / 25 / 16,6-7 \mathrm{pm}$ \\
\hline August & 7.024 & $8 / 3 / 16,5-6 \mathrm{pm}$ & 9.144 & $8 / 3 / 16,4-5 \mathrm{pm}$ \\
\hline September & 4.315 & -- & 8.070 & -- \\
\hline Total period & 7.024 & $8 / 3 / 16,5-6 \mathrm{pm}$ & 7.201 & $2 / 26 / 16,4-5 \mathrm{am}$ \\
\hline
\end{tabular}

Comparing Table 12 to Table 6 it can be noted that the Trilogy system peak demand was generally higher at the Oklahoma City site than that experienced at the Knoxville site. This can be seen in Figures 18-21 below for February, June, July, and August peak weeks, respectively (compare to Figure 16 which illustrates a peak week at the Knoxville site). There are a number of factors contributing to this difference. One is that the Trilogy WSHPs at the homeless shelter were configured to deliver a maximum cooling capacity of 5 tons due to the higher design loads at the shelter vs. at the commercial kitchen in Knoxville. The higher SC loads at the shelter required the Trilogy to run at generally higher compressor drive frequencies $(\mathrm{Hz})$ and, thus, higher compressor speeds, reaching peaks of almost $70 \mathrm{~Hz}$ ( 4200 compressor rpm) at times. In contrast, the Trilogy unit at the Knoxville site seldom experienced compressor drive frequencies higher than about $40 \mathrm{~Hz}$. Hourly SH or SC energy use (aka hourly power demands) for the IHPs at the Oklahoma City location were therefore higher.

Secondly, WH demands at the shelter were larger and more constant than at the Knoxville kitchen facility. This resulted in more frequent use of the backup electric elements in the WH tanks than was seen in Knoxville. While the total usage of the elements at the shelter was modest ( $19 \mathrm{kWh}$ from MaySeptember), at times element operation coincided with peak AC demand periods. This resulted in occasional sharp, short term peaks in the summer months for the IHP system as seen in Figures 19-21 when the Trilogy system peak approached 6-7kW. [Note: as for Figure 16, the IHP and tank element power values in Figures 18-21 are divided by 100.] Application of control strategies to prohibit or minimize back-up WH element usage during peak times could hold the IHP hourly peaks to $<4 \mathrm{~kW}$. 
Hourly averages (temperatures, ${ }^{\circ} \mathrm{F}$ ) or totals (gallons, $\mathrm{Wh} / 100$ )

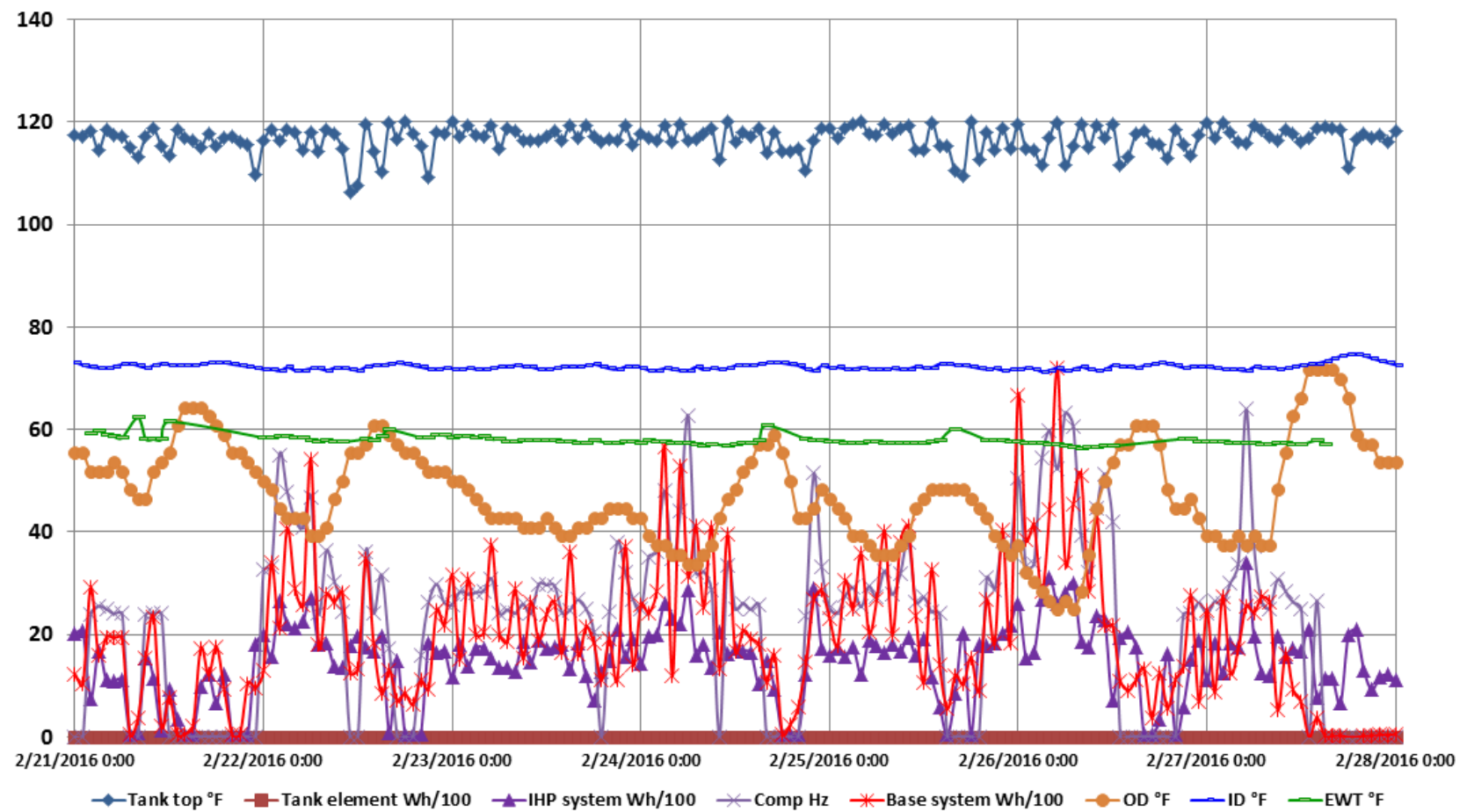

Figure 18. Oklahoma City: Maximum SH season IHP hourly peak demand week

Note that for the February peak week plot in Figure 18 there was no IHP system WH energy delivery data for reasons noted elsewhere in the report. The IHP energy use data, however, do reflect WH mode operation as can be seen most clearly by the data for the last half of February 27. The compressor drive $\mathrm{Hz}$ (light purple line) plotted in Figure 18 is only for the $\mathrm{SH}$ mode and note that it drops to zero but the IHP energy use (dark purple line) continues to show it in operation. During that period the IHP was operating in WH mode only. The back-up electric elements in the IHP WH tank were also being monitored but as can be seen by the heavy dark red line along the $x$-axis in Figure 18, the elements were never active throughout this week - e.g., the entire WH load was served by the Trilogy unit both for this peak week and essentially for the entire January 31 through April 28 period. Total backup element energy use recorded by the DAQ for January-April was only $\sim 1 \mathrm{Wh}$. 
Hourly averages (temperatures, ${ }^{\circ} \mathrm{F}$ ) or totals (gallons, Wh/100)

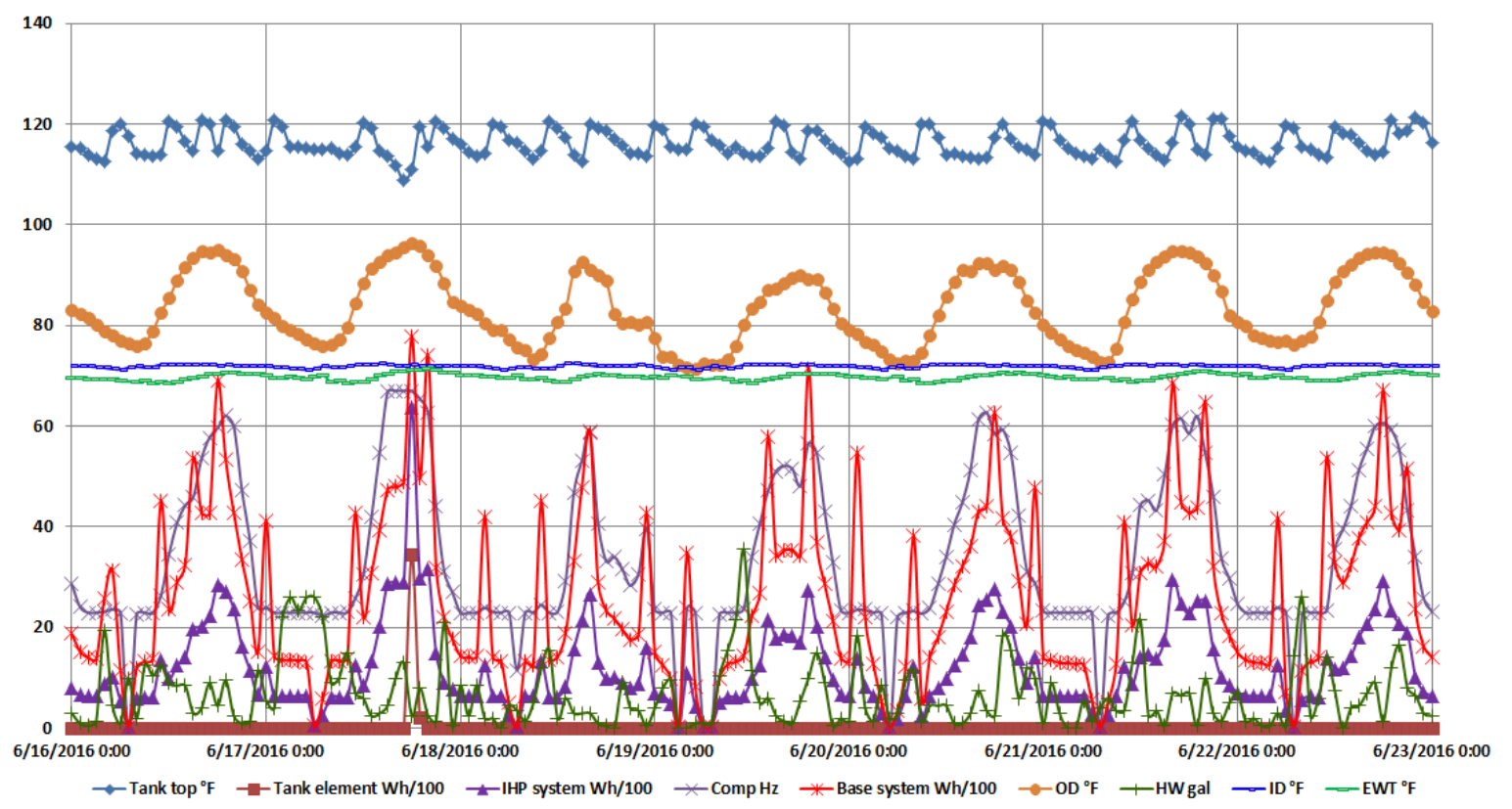

Figure 19. Oklahoma City: June IHP hourly peak demand week

Hourly averages (temperatures, ${ }^{\circ} \mathrm{F}$ ) or totals (gallons, Wh/100)

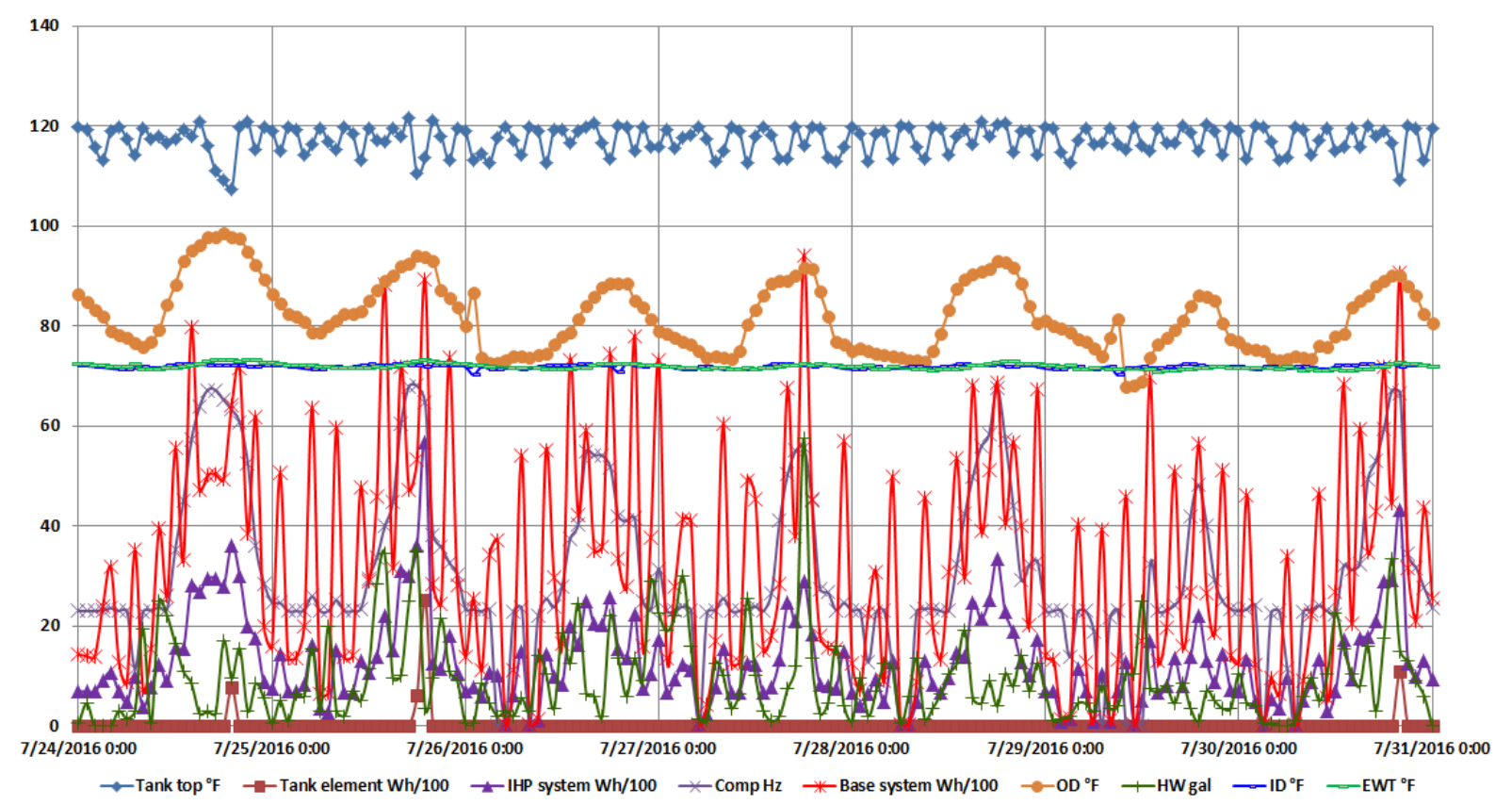

Figure 20. Oklahoma City: July IHP hourly peak demand week 


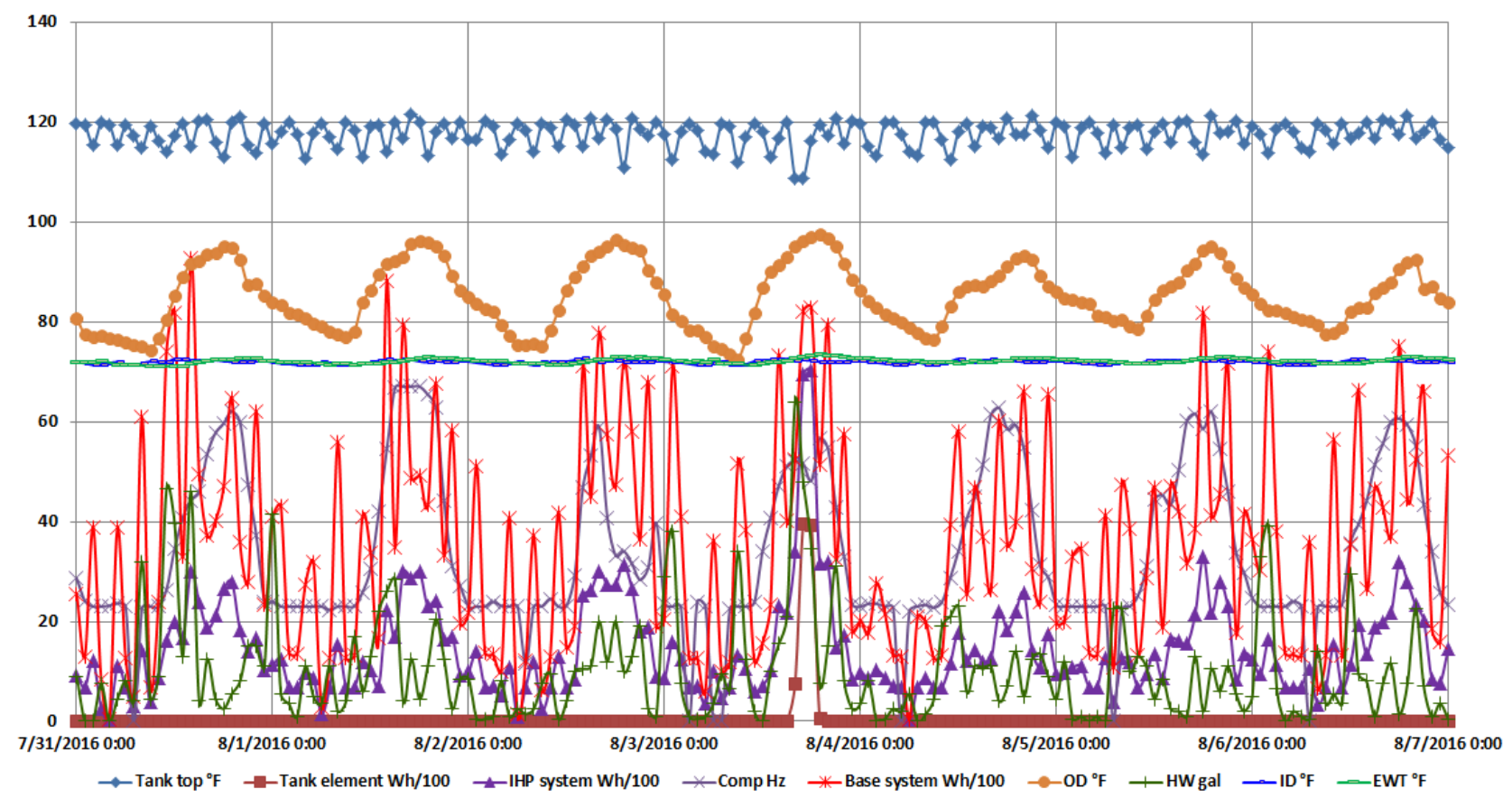

Figure 21. Oklahoma City: August IHP hourly peak demand week

\section{Cost analysis for Knoxville site}

A payback analysis is given in Table 13, based on the Knoxville system design. Equipment cost details for the base RTU/HP system and high and low costs for the GS-IHP are given in section IV.E above. Three GS-IHP cost assumptions are given in Table 13. The "high" cost assumption uses the GHX cost as billed by the contractor for the Knoxville site. A "low" cost assumption is given based on the contractors' estimate that GHX cost could have been up to one third of the actual cost absent the "out of normal" conditions experienced as discussed in IV.E. Next is a "mature market" cost assumption based on experience with a large number of installations in Oklahoma. Finally, an alternative GHX financing approach is considered. For this case it is assumed that the utility installs and owns the GHX (e.g. under an ESPC or utility energy savings contract (USEC), etc.). ${ }^{27}$ A GHX cost recovery charge of $2 \%$ of the GHX installation cost (for the mature market case) is added to the electric bill, reducing the total annual

\footnotetext{
${ }^{27}$ An example of this approach is a program being undertaken by Western Farmer's Electric Cooperative, described in the article "In the Loop" by Robert Cunningham (October 5, 2015) in the Rural Electric Magazine web edition, http://remagazine.coop/in-the-loop/, accessed August 31, 2016. A quote taken from the article --- "Meanwhile, Western Farmers Electric has been working with several distribution co-ops to test the economics of a "thermal service" program option where the latter would build, own, and maintain the underground loop and provide it to their members as a utility service at a fixed monthly rate. . . . . this option presents opportunities like the chance to deploy new and innovative business models to deliver the benefits of GSHPs to members and provide a new, stable revenue stream."
} 
energy cost savings to the building owner. ${ }^{28}$ Using the energy cost savings from Table 7, the payback for the GS-IHP ranges from $~ 8.5$ to $>30$ years for the low and high GHX cost ranges assuming the building owner pays the cost of the GHX installation up front. Assuming the utility installs and owns the GHX (building owner pays only for the Trilogy and associated indoor installation); the payback period could drop to $\sim 0.3$ year.

Table 13. Payback analysis - Knoxville

\begin{tabular}{|c|c|c|c|c|c|c|c|}
\hline & Equi & $\begin{array}{l}\text { ent costs } \\
\text { (\$) }\end{array}$ & $\begin{array}{c}\text { GHX } \\
\text { installed }\end{array}$ & $\begin{array}{l}\text { Total } \\
\text { Cost }\end{array}$ & $\begin{array}{c}\text { Cost } \\
\text { Difference }\end{array}$ & $\begin{array}{c}\text { Energy } \\
\text { Cost }\end{array}$ & $\begin{array}{c}\text { Payback } \\
\text { (yrs) }\end{array}$ \\
\hline & Price & Installation & cost (\$) & (S) & (\$) & $\begin{array}{l}\text { Savings } \\
\text { (\$) }\end{array}$ & \\
\hline $\begin{array}{l}\text { Conventional } \\
\text { RTU/HP and } \\
\text { electric WH }\end{array}$ & 4,100 & 7,200 & na & 11,300 & & & \\
\hline $\begin{array}{l}\text { GS-IHP; high GHX } \\
\text { cost assumption }\end{array}$ & 9,800 & 1,600 & 38,000 & 49,400 & 38,100 & 1172 & 32.5 \\
\hline $\begin{array}{l}\text { GS-IHP; low GHX } \\
\text { cost assumption }\end{array}$ & 9,800 & 1,600 & 15,000 & 26,400 & 15,100 & 1172 & 12.9 \\
\hline $\begin{array}{l}\text { GS-IHP; mature } \\
\text { market cost }\end{array}$ & 9,800 & 1,600 & 9,600 & 21,000 & 9,700 & 1172 & 8.3 \\
\hline $\begin{array}{l}\text { GS-IHP; mature } \\
\text { market GHX cost; } \\
\text { utility owns GHX } \\
\text { assumption }\end{array}$ & 9,800 & 1,600 & na & 11,400 & 100 & 980 & 0.1 \\
\hline
\end{tabular}

${ }^{\text {a }}$ Utility adds cost recovery surcharge totaling $2 \%$ of GHX installation cost per year to bill $(\$ 192)$.

\section{Summary Findings and Recommendations}

\section{A. Overall Technology Assessment at Demonstration Facility}

For the August 2015 through August 2016 period, the Knoxville site GS-IHP provided $53.7 \%$ total source energy savings compared to a baseline electric RTU/heat pump and electric WH. Peak demand savings ranged from $54 \%$ to $78 \%$ per month. Energy savings of $54.6 \%$ and energy cost savings of $55.9 \%$ have been achieved (about evenly split between reduced demand charges and electricity consumption savings). The GS-IHP also saved a significant amount of carbon emissions - 2.45 metric tons for the August 2015 to August 2016 test year. If trading for carbon credits ever becomes a reality, additional cost savings would be realized. These savings significantly exceeded the project technical performance

\footnotetext{
${ }^{28}$ The $2 \%$ figure was chosen based on the typical default rate for such on bill financing (OBF) programs as noted in the report "Measuring the Costs and Benefits of Nationwide Geothermal Heat Pump Deployment," by E. C. Battocletti and W. E. Glassley, prepared for the USDOE Geothermal Technologies Program, February 2013.
} 
goal of $\geq 45 \%$ energy and carbon emission reductions. For this site, no SH loads were experienced; only SC and WH operation was required for the entire test year.

For the Oklahoma City site delays in completing installation of the DAQ system prevented collection of a full year of performance data. However enough data was obtained to allow a reasonable estimate of $\mathrm{SH}, \mathrm{SC}$, and $\mathrm{WH}$ energy savings and efficiency vs. the baseline system.

- $\mathrm{SH}$ : from Table 8, total energy savings of $\sim 753 \mathrm{kWh}(\sim 52 \%)$ and average COP of $\sim 4.9$

- SC: from Table 9, total energy savings of $\sim 1847 \mathrm{kWh}(\sim 50 \%)$ and average COP of $\sim 6.9$

- WH: from Table 10, total energy savings of $\sim 2293 \mathrm{kWh}(\sim 78 \%)$ and average COP of $\sim 4.4$ Over the actual monitoring period, the GS-IHP at the site demonstrated total site electricity savings of $\sim 4890 \mathrm{kWh}(\sim 60 \%)$ and carbon emission savings of $\sim 3.4$ metric tons, greatly exceeding the project technical goal. Assuming that the daily average loads and COPs above are the same for the balance of the year for each mode it is estimated that total annual energy savings would be $12,460 \mathrm{kWh}$ with carbon emission savings of $\sim 8.6$ metric tons. Note that these numbers can be assumed to be double ( $\sim 24,900 \mathrm{kWh}$ and $\sim 17.2$ metric tons) since the shelter building had two GS-IHP units (the second unit was not monitored). Note that the WH savings indicated above are estimated assuming that the system at Oklahoma City experienced the same HW tank and connecting line standby heat losses (as a percentage of the total load) that were measured at the Knoxville site.

This field study successfully demonstrated the energy savings, environmental savings, and operational benefits of the GS-IHP technology for small commercial building applications. Both demonstration systems significantly exceeded the project technical objectives of $>45 \%$ energy and carbon emission savings ( $>50 \%$ at both sites). Best applications of the GS-IHP system are buildings or specific small zones of buildings that have high hot water loads coincident with high space cooling loads.

Payback analyses were conducted for the Knoxville site system based on the annual energy savings demonstrated. The specific site conditions (limited area, local regulations, etc.) caused drilling costs to be about 3 times higher than typical for the area. For the actual GHX cost, simple payback vs. the baseline RTU/HP/electric WH system were $>30$ years (Table 13). With more typical GHX costs for the area the payback is approximately 13 years. For a "mature market" cost assumption based on experience in Oklahoma for a large number of installations the payback drops to 8 years, still likely higher than acceptable for most commercial building owners. Assuming an alternative GHX financing option where the local utility (or other entity) installed and owned the GHX loop and amortized the cost via a surcharge on the electric bill were available, system payback could be reduced to $\sim 0.1$ year.

The only reported service need during the duration of the field test was the failure of the main control board at start up in Knoxville. The manufacturer provided a replacement under the warranty and no further incidents were experienced at either site. 


\section{B. Market Potential and Recommendations}

Based on demonstrated performance at the Knoxville site, if applied nationally to all appropriate commercial building spaces, GS-IHPs could save 0.084 quads of source energy vs. a 13 SEER RTU/heat pump and electric WH baseline. The actual utility bill savings for a building owner will depend on a number of factors, most notably the building's climate region, HVAC and DHW load profiles, and regional utility rates. As noted earlier, best performance and highest energy and energy cost savings would occur in applications that have high water heating loads coincident with high space cooling loads (commercial kitchens, laundries, restaurants, dormitory-like buildings, etc.).

These particular demonstrations were located in Knoxville and Oklahoma City. The Knoxville site was a small commercial kitchen which experienced a year-round SC load and fairly heavy HW demands during the work week (M-F). At Oklahoma City, a homeless shelter (dormitory-like facility) was used which featured relatively balanced SH and SC and WH loads with SC being the largest. Both sites allowed the GS-IHP to take advantage of its combined SC+WH mode featuring fairly extensive recovery of the normally wasted system condenser heat for water heating.

The economics of GS-IHPs will vary from site to site for several reasons, including:

- Regional differences in drilling costs, local site conditions and requirements, and financing options can cause the GHX loop installation costs to vary over a wide range even within a given region. Where local site conditions are unfavorable (restricted area, local permitting/regulation restrictions, etc. as experienced at the Knoxville site) GHX installation costs can be prohibitive

- Local electricity rate structures may limit the operating cost savings achievable, leading to higher payback periods.

Increasing the adoption of high-efficiency integrated HVAC/WH systems like the GS-IHP will require a change in the way HVAC contractors, design engineers, and building owners and operators consider them due to their increased installation cost. Raising awareness of the availability and the potential lifetime energy savings of GS-IHPs may encourage more industry professionals to evaluate them for their buildings, and determine whether the systems offer an acceptable payback based on climate, operations, building design, etc. Additionally, system designers have difficulty using popular building modeling tools to evaluate nonconventional equipment.

The following actions are recommended for promoting adoption of GS-IHP technology, including: 
For Developers of Building Energy Modeling Tools:

- Design specific equipment modules for GS-IHP and include as an option within the modeling software

For DOE and Other Efficiency Organizations:

- Facilitate quick energy savings calculations by developing a simple set of regional climate maps estimating equipment runtimes for different scenarios

- Develop best practice guides based on evaluations against different baseline equipment and building types.

For Electric Utilities:

- Educate commercial customers on the life-cycle cost of GS-IHP technologies and include them in available grant, incentive, or financing programs.

For Local/State Government Agencies, Electric Utilities, Other Efficiency Organizations:

- Consider promoting and/or establishing specific financing options for GHX loops for commercial customers

- Consider promoting and/or establishing incentives for GS-IHP systems for commercial customers

\section{Acknowledgements}

The authors express thanks to Mr. Shawn Hern and Mr. Jeremy Smith (ClimateMaster, Inc.) for donating the WSHPs necessary for the field demonstrations and their contributions to this project and report. We also thank Mr. Mike Davis (City Heat \& Air Conditioning, Knoxville, TN), and Mr. Dan Ellis (Comfortworks, Inc., Goldsby, OK) for their contributions to this project and this report. Finally we thank our colleagues at ORNL: Geoff Ormston for assistance in preparation and installation of the site data monitoring systems, Randy Linkous for assistance in preparing baseline system installation cost estimates, and Melissa Lapsa (leader of the CBI program work at ORNL) for guidance and direction during the course of the project. This report and the work described herein were funded by the Commercial Buildings Integration (CBI) program of the U.S. Department of Energy Building Technologies Office (DOE/BTO) under Contract No. DE-AC05-00OR22725 with UT-Battelle, LLC. 
Building Technologies Program

techdemo@ee.doe.gov

ORNL/TM-2016/474 • September 2016

Printed with a renewable-source ink on paper containing at least $50 \%$ wastepaper, including $10 \%$ post-consumer waste. 